\title{
Antifungal activity of redox-active benzaldehydes that target cellular antioxidation
}

\author{
Jong H Kim, Kathleen L Chan, Noreen Mahoney and Bruce C Campbell
}

\begin{abstract}
Background: Disruption of cellular antioxidation systems should be an effective method for control of fungal pathogens. Such disruption can be achieved with redox-active compounds. Natural phenolic compounds can serve as potent redox cyclers that inhibit microbial growth through destabilization of cellular redox homeostasis and/or antioxidation systems. The aim of this study was to identify benzaldehydes that disrupt the fungal antioxidation system. These compounds could then function as chemosensitizing agents in concert with conventional drugs or fungicides to improve antifungal efficacy.

Methods: Benzaldehydes were tested as natural antifungal agents against strains of Aspergillus fumigatus, A. flavus, A. terreus and Penicillium expansum, fungi that are causative agents of human invasive aspergillosis and/or are mycotoxigenic. The yeast Saccharomyces cerevisiae was also used as a model system for identifying gene targets of benzaldehydes. The efficacy of screened compounds as effective chemosensitizers or as antifungal agents in formulations was tested with methods outlined by the Clinical Laboratory Standards Institute (CLSI).

Results: Several benzaldehydes are identified having potent antifungal activity. Structure-activity analysis reveals that antifungal activity increases by the presence of an ortho-hydroxyl group in the aromatic ring. Use of deletion mutants in the oxidative stress-response pathway of $S$. cerevisiae ( $\operatorname{sod} 1 \Delta, \operatorname{sod} 2 \Delta, \mathrm{g} / \mathrm{r} 1 \Delta$ ) and two mitogen-activated protein kinase (MAPK) mutants of $A$. fumigatus (sakA $\triangle, m p k C \Delta$ ), indicates antifungal activity of the benzaldehydes is through disruption of cellular antioxidation. Certain benzaldehydes, in combination with phenylpyrroles, overcome tolerance of A. fumigatus MAPK mutants to this agent and/or increase sensitivity of fungal pathogens to mitochondrial respiration inhibitory agents. Synergistic chemosensitization greatly lowers minimum inhibitory (MIC) or fungicidal (MFC) concentrations. Effective inhibition of fungal growth can also be achieved using combinations of these benzaldehydes.
\end{abstract}

Conclusions: Natural benzaldehydes targeting cellular antioxidation components of fungi, such as superoxide dismutases, glutathione reductase, etc., effectively inhibit fungal growth. They possess antifungal or chemosensitizing capacity to enhance efficacy of conventional antifungal agents. Chemosensitization can reduce costs, abate resistance, and alleviate negative side effects associated with current antifungal treatments.

\section{Background}

A number of different cellular targets of conventional antifungal drugs have already been identified. Examples include mitochondrial respiration, cell wall/membrane integrity, cell division, signal transduction, and macromolecular synthesis, etc. [1]. However, conventional antifungal drugs (including fungicides) also cause serious mammalian cytotoxicity, partly through the intracellular production of reactive oxygen species (ROS) [2].

\footnotetext{
* Correspondence: bruce.campbell@ars.usda.gov

Plant Mycotoxin Research Unit, Western Regional Research Center, USDAARS, 800 Buchanan St., Albany, CA 94710, USA
}

Emerging resistance to currently available antifungal drugs and a deficiency in discovery of new ones engender urgency for development of new antifungal agents and/or alternative therapies for control of fungal pathogens [3-7].

Natural compounds that do not have any significant medical or environmental impact are a potential source of antimycotic agents, either in their nascent form or as template structures for more effective derivatives $[8,9]$. Prior studies showed that analogs of benzoic or cinnamic acids, common phenolics found in edible plants, inhibit biosynthesis of mycotoxins and growth of various

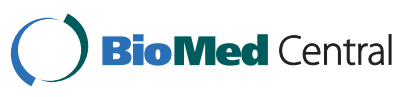

(c) 2011 Kim et al; licensee BioMed Central Ltd. This is an Open Access article distributed under the terms of the Creative Commons Attribution License (http://creativecommons.org/licenses/by/2.0), which permits unrestricted use, distribution, and reproduction in any medium, provided the original work is properly cited. 
fungi, both filamentous and yeasts [10-12]. Noteworthy is that these phenolics can be potent redox cyclers that inhibit microbial growth through disruption of cellular redox homeostasis and/or antioxidation systems [13,14].

From a clinical perspective, the functions of antioxidation systems $[e, g$., mitogen-activated protein kinases (MAPKs)], two-component histidine kinase and antioxidation enzymes [e.g., superoxide dismutases (SODs), catalase, etc.], have been implicated as factors important to the virulence of fungal pathogens $[15,16]$. In Aspergillus fumigatus, $\mathrm{Cu}, \mathrm{Zn}$-SOD detoxifies ROS produced by host defense systems [17]. Fungi require well defined regulation of expression of antioxidation systems, not only for protection from host defense responses, but also for maintaining redox homeostasis needed for normal fungal growth $[18,19]$. Because of this pivotal role, destabilization of antioxidation systems can be an effective way to control fungal pathogens. Such destabilization may be possible with redox-active compounds.

Inhibitors of the mitochondrial respiratory chain (MRC), such as antimycin A or mucidin, disrupt cellular energy production in fungi $[20,21]$, decreasing cell viability. Coinciding with this disruption is an abnormal release of electrons from the chain. This surfeit of electrons further stresses cellular components through oxidative damage resulting in apoptosis or necrosis [21,22]. As indicated above, the cellular antioxidation system $[e$. g., cytosolic superoxide dismutase (Cu, $\mathrm{Zn}-\mathrm{SOD})$, mitochondrial superoxide dismutase (Mn-SOD), glutathione reductase, etc.] plays an important defensive role in protecting fungal cells from such oxidative species [23,24].

Other studies have also shown that antimicrobial activity of a variety of drugs can be linked to cellular oxidative stress. Examples include ciprofloxacin, a fluoroquinolone antibiotic inhibiting DNA topoisomerases ([25] and references therein). After treatment of ciprofloxacin, the level of ROS was increased in bacterial pathogens. However, application of antioxidants, such as reduced glutathione (GSH) or ascorbic acid, reversed the toxicity of fluoroquinolones. In addition, transfection of SOD genes into bacteria also resulted in greater survival of cells exposed to these drugs [25], indicating ROS (i.e., superoxides, peroxides, etc.) are involved in antimicrobial activity of ciprofloxacin. Amphotericin B (AMB), a polyene antifungal drug, is another example. Although AMB is known as a fungicidal drug, studies have shown that addition of antioxidants, such as GSH, cysteine, etc., could revive endospores of Coccidioides immitis treated with AMB ([26] and references therein). Other data also indicate involvement of cellular oxidative stress in the antifungal action of AMB $[27,28]$.

Co-application of certain types of compounds can enhance effectiveness of conventional antimicrobial agents through a process termed chemosensitization. In this case, a chemosensitizing agent functions by debilitating the ability of a pathogen to completely activate a defense response to an antimicrobial agent $[29,30]$. A chemosensitizing agent does not necessarily require a great degree of antimicrobial potency, itself, to be effective.

The chief value of chemosensitization, especially by safe natural compounds, is lowering of dosage levels of commercial drugs required for control of pathogens; thus, lowering costs and risks of negative side effects. Redox-active natural compounds that destabilize the fungal antioxidation system could act as potent chemosensitizing agents when co-applied with oxidative stress drugs, such as MRC inhibitors, for control of fungal pathogens. Thus, chemosensitization could make the use of toxic antifungal drugs or fungicides more attractive as a chemotherapeutic strategy, and to overcome development of pathogen resistance to conventional antimicrobial agents.

Filamentous fungi in the genus Aspergillus are notable etiological agents of a highly debilitating human disease, invasive aspergillosis [31]. Among these are A. fumigatus, A. terreus and A. flavus, ubiquitous opportunistic pathogens. A. flavus also produces hepatocarcinogenic aflatoxins that are a major food safety issue in that they can contaminate a variety of edible crops and their byproducts [32]. Likewise, another mycotoxin, patulin [4hydroxy- $4 H$-furo $(3,2 \mathrm{C})$ pyran-2 $(6 H)$-one], that can contaminate fruits, causes serious acute/chronic cellular or target-organ toxicity in mammals by disrupting cellular $[33,34]$ and enzymatic $[35,36]$ processes. Patulin is most commonly produced by fungi in the genera Aspergillus and Penicillium [37,38]. Among these, P. expansum is of highest food safety concern with regard to patulinproduction.

The yeast Saccharomyces cerevisiae is a useful model system for identifying antifungal agents and their gene targets in view that: (1) the genome of S. cerevisiae has been sequenced and well annotated ([39], accessed March 1, 2011); (2) S. cerevisiae gene deletion mutants have proven to be very useful for identifying the mechanism/target genes of antimicrobial agents [40]; and (3) many genes in S. cerevisiae are orthologs of genes of fungal pathogens [41]. For example, we recently confirmed structural homology of signal transduction and antioxidation genes between S. cerevisiae and the filamentous fungus A. flavus [42].

In this study, we identify safe natural phenolics, which can specifically disrupt the fungal antioxidation system. As potent redox cyclers, phenolic compounds can effectively debilitate the cellular redox homeostasis/antioxidation system in fungi, resulting in the suppression of fungal growth. We describe a bioassay, using S. cerevisiae as a model, which provides a framework for 
examining structure-activity relationships of screened compounds and for identifying promising molecular targets. In this study, we focus on effectiveness of structural analogs of benzaldehyde to identify: (1) the most effective antifungal target in the mitochondrial respiratory chain (MRC); (2) the most effective analogs as antifungal agents; and (3) the fungal antioxidation system as the target of the benzaldehydes. In addition, we examine if benzaldehydes can serve as chemosensitizing agents or as antifungal agents, in combination amongst themselves, at the micromolar level.

\section{Methods}

\section{Microorganisms}

Aspergillus fumigatus AF293 (wild type), and A. fumigatus MAPK deletion mutants sakA $\Delta$ and $m p k C \Delta[43,44]$ were grown at $35^{\circ} \mathrm{C}$ on potato dextrose agar (PDA). $A$. terreus UAB673, UAB680 and UAB698, clinical strains from aspergillosis patients, were obtained from Centers for Disease Control and Prevention, Atlanta, GA, and were grown at $35^{\circ} \mathrm{C}$ on PDA. Also, A. flavus NRRL3357 and Penicillium expansum NRRL974, obtained from the National Center for Agricultural Utilization and Research, USDA-ARS, Peoria, IL, were grown at $28^{\circ} \mathrm{C}$ on PDA. Temperatures used were the optimum temperatures for each strain. Saccharomyces cerevisiae wild type BY4741 (Mat a his $3 \Delta 1$ leu $2 \Delta 0$ met $15 \Delta 0$ ura $3 \Delta 0$ ) and selected single gene deletion mutants, i.e., cytosolic superoxide dismutase $(\mathrm{Cu}, \mathrm{Zn}-\mathrm{SOD})$ mutant $(\operatorname{sod} 1 \Delta)$, mitochondrial superoxide dismutase (Mn-SOD) mutant $(\operatorname{sod} 2 \Delta)$ and glutathione reductase mutant $(g \operatorname{lr} 1 \Delta)$, were obtained from Invitrogen (Carlsbad, CA) and Open Biosystems (Huntsville, AL; [39], accessed March 1, 2011). Yeast strains were cultured on SG (Yeast nitrogen base without amino acids $0.67 \%$, glucose $2 \%$ with appropriate supplements: uracil $0.02 \mathrm{mg} / \mathrm{ml}$, amino acids $0.03 \mathrm{mg} /$ $\mathrm{ml}$ ) agar at $30^{\circ} \mathrm{C}$.

\section{Chemicals}

Benzaldehyde (basal compound) and its structural analogs (twenty-one new benzaldehyde derivatives), i.e., cinnamaldehyde, 2-hydroxy-3-methoxybenzaldehyde (o-vanillin), 2hydroxy-5-methoxybenzaldehyde, 2-methylbenzaldehyde (o-tolualdehyde), 3-methylbenzaldehyde ( $m$-tolualdehyde), 4-methylbenzaldehyde ( $p$-tolualdehyde), 2-methoxybenzaldehyde ( $o$-anisaldehyde), 3-methoxybenzaldehyde ( $m$-anisaldehyde), 4-methoxybenzaldehyde ( $p$-anisaldehyde), 2,3dimethoxybenzaldehyde, 2,4-dimethoxybenzaldehyde, 2,5dimethoxybenzaldehyde, 3,5-dimethoxybenzaldehyde, 2,4,5-trimethoxybenzaldehyde, 4-hydroxy-2-methoxybenzaldehyde, 3,5-dimethoxy-4-hydroxybenzaldehyde (syringaldehyde), 3,5-dimethoxy-4-hydroxycinnamaldehyde, 4methoxy-2-methylbenzaldehyde, 2-hydroxy-5-methylbenzaldehyde, 2,4-dimethylbenzaldehyde, 4-diethylamino-2- hydroxybenzaldehyde, two phenolics (cell wall/membrane integrity disruptors) [2,3-dihydroxybenzaldehyde (2,3-D), thymol], strobilurins [pyraclostrobin (PCS), kresoxim methyl (Kre-Me)] and other chemicals [antimycin A (AntA), carboxin, thenoyltrifluoroacetone (TTFA), rotenone, 3-nitropropionic acid (3-NPA), benzhydroxamic acid (BHAM), salicylhydroxamic acid (SHAM), potassium cyanide $(\mathrm{KCN})$, fludioxonil, glutathione ( $\mathrm{GSH}$, reduced form; GSSG, oxidized form), dimethyldithiocarbamate (DDC)] were procured from Sigma Co. (St. Louis, MO, USA). Each compound was dissolved in dimethylsulfoxide (DMSO; absolute DMSO amount: < $2 \%$ in media), except glutathione, which was dissolved in water, before incorporation into culture media. In all tests, control plates (i.e., "No treatment") contained DMSO at levels equivalent to that of cohorts receiving antifungal agents, within the same set of experiments (See Figures).

\section{Antifungal bioassays \\ Plate (agar) bioassay}

Measurement of sensitivities of filamentous fungi to the structural analogs of benzaldehyde was based on percent radial growth of treated compared to control fungal colonies (Test concentrations: 0, 0.5, 1.0, 1.5, 2.0, 2.5, $3.0 \mathrm{mM}$ ). The percent inhibition of growth was calculated using the Vincent equation [45] [\% inhibition = $100(\mathrm{C}-\mathrm{T}) / \mathrm{C}$; where $\mathrm{C}=$ diameter of fungal colony on control plate (receiving only DMSO), and $\mathrm{T}=$ diameter of fungal colony on the treated plate]. Minimum Inhibitory Concentration (MIC) values on agar plates were based on triplicate assays and defined as the lowest concentration of agent where no fungal growth was visible on the plate. For the above assays, fungal conidia $(5 \times$ $10^{3}$ ) were diluted in phosphate buffered saline and applied as a drop onto the center of PDA plates with or without antifungal compounds. Growth was observed for three to seven days.

Petri plate-based yeast dilution bioassays were performed on the wild type and antioxidation mutants $(\operatorname{sod} 1 \Delta, \operatorname{sod} 2 \Delta, \operatorname{glr} 1 \Delta)$ to assess effects of screened compounds on the antioxidation system. Yeast strains were exposed to 0.1 to $1.5 \mathrm{mM}$ of seven benzaldehyde analogs screened. These assays were performed in duplicate on SG agar following previously described protocols [46]

\section{Microdilution (microtiter) bioassay}

Levels and types of compound interactions between antifungal agents were based on Fractional Inhibitory Concentration Indices (FICI) [47], where FICI $=(\mathrm{MIC}$ of compound $\mathrm{A}$ in combination with compound $\mathrm{B} / \mathrm{MIC}$ of compound A, alone) + (MIC of compound B in combination with compound $\mathrm{A} / \mathrm{MIC}$ of compound $\mathrm{B}$, alone). Compound interactions were defined as synergistic $(\mathrm{FICI} \leq 0.5)$, additive $(0.5<\mathrm{FICI} \leq 1)$, neutral $(1<$ $\mathrm{FICI} \leq 2)$ or antagonistic $(2<\mathrm{FICI})$. 
To determine antifungal MICs in microtiter wells for use in calculating FICIs, triplicate assays $\left(4 \times 10^{4}\right.$ conidia/ $\mathrm{ml}$ ) were performed using a broth microdilution according to methods outlined by the Clinical Laboratory Standards Institute (CLSI) M38-A [48]. RPMI 1640 medium (Sigma Co.) was supplemented with $0.03 \%$ L-glutamine and buffered with $0.165 \mathrm{mM} 3$-[N-morpholino] propanesulfonic acid. Concentrations of test compounds used for chemosensitization assays were as described in the text.

\section{Formulation studies of benzaldehydes}

Formulation studies included $o$-vanillin, 2-hydroxy-5methoxybenzaldehyde, cinnamaldehyde, which showed the highest antifungal activities (Group A benzaldehydes: See below) and two additional phenolic agents, 2,3-dihydroxybenzaldehyde (2,3-D) and thymol, found in a prior study to disrupt cell wall/membrane integrity [46]. Compounds were tested either singularly or combined in formulations that included all five compounds. Antifungal efficacies of singular compounds $v s$. formulations were compared. Treatments included the compounds at 2, 4, 8, 16, 32, 64 or $128 \mu \mathrm{g} / \mathrm{ml}$ alone, or all together in equal amounts at these same concentrations (e.g., mixtures of $2 \mu \mathrm{g} / \mathrm{ml}$, each, $4 \mu \mathrm{g} / \mathrm{ml}$, each, etc., of all five compounds), to determine MICs and Minimum Fungicidal Concentrations (MFCs) of the compounds individually and as formulations. All assays were performed in triplicate in 96-well microtiter plates (48 hrs incubation for determining MICs).

The level of antifungal efficacy of a formulation was evaluated by determining ratio of MFC/MIC. To obtain MFC values, the entire volume of each well $(200 \mu \mathrm{l}$ per well) from microtiter plates (at $48 \mathrm{hrs}$ of incubation) was spread onto independent PDA plates, and cultured for an additional $48 \mathrm{hrs}$ at temperatures respective for each fungus (See above). MFC was defined as the lowest concentration of agent where > 99.9\% fungal death occurred, as determined by cell growth on the agar plate. If $\mathrm{MFC}_{\mathrm{FORMULATION}} / \mathrm{MIC}_{\mathrm{FORMULATION}}$ was $\leq 4$, the formulation was defined as fungicidal, whereas if $\mathrm{MFC}_{\text {FORMULATION }} / \mathrm{MIC}_{\text {FORMULATION }}$ was $>4$, the formulation was defined as fungistatic [49].

Assessment of compound formulations was measured by formulation efficacy (FE), i.e., $\mathrm{FE}_{\mathrm{MIC}}$ or $\mathrm{FE}_{\mathrm{MFC}}$. Respective FEs were calculated, as follows: $\mathrm{FE}_{\mathrm{MIC}}=(\mathrm{MIC}$ of compound $\mathrm{A}$, alone $\left./ \mathrm{MIC} \mathrm{FORMULATION}_{\mathrm{F}}\right)$ or $\mathrm{FE}_{\mathrm{MFC}}=(\mathrm{MFC}$ of compound $\mathrm{A}$, alone/MFC $\mathrm{FORMULATION}_{\text {), respectively. We }}$ defined FE as (a) no effect, if FE $\leq 1$, (b) low (L), if $1<$ FE $<4$, or $(\mathrm{c})$ high $(\mathrm{H})$, if $\mathrm{FE} \geq 4$ (See also table 4 ).

\section{Results}

Complexes II and III as the most effective antifungal targets in the mitochondrial respiratory chain (MRC)

Since various antifungal agents inhibit different components of the MRC at varying levels, we initially attempted to identify the most effective antifungal target (s) within this chain. We tested eleven conventional antifungal agents, which disrupt the functions of complexes I, II, III, IV or alternative oxidases (AOX) in the MRC, using A. fumigatus AF293 as a representative fungal pathogen (Figure 1A).

Targeting MRC complex II of A. fumigatus AF293 with thenoyltrifluoroacetone (TTFA) or carboxin, or complex III with antimycin A (AntA) or strobilurins [ $i$. e., kresoxim methyl (Kre-Me)/pyraclostrobin (PCS)], resulted in greater inhibition of fungal growth (Vincent equation: $36 \%$ - 84\%) compared to targeting other MRC complexes (Vincent eq.: 0\% - 14\%) (Figure 1B). Results also indicated that complex III inhibitors possessed higher antifungal activity (Vincent eq.: 60\% - 84\%) than complex II inhibitors (Vincent eq.: 36\% - 48\%). In our test, the complex II inhibitor 3-nitropropionic acid (3NPA) had no discernable growth inhibitory effect on $A$. fumigatus. Neither did the complex I inhibitor, rotenone (Rot.), AOX inhibitors, benz- or salicyl-hydroxamic acids (BHAM, SHAM), nor complex IV inhibitors potassium cyanide $(\mathrm{KCN})$ and sodium azide (Na-azide) (Figure $1 \mathrm{~B})$. DMSO is a good solvent for polar and nonpolar compounds, is miscible in varying organic substances and is widely used to enhance absorption for drug-delivery [50]. We considered that the individual MRC inhibitors tested were absorbed at equivalent levels by fungal cells. However, future studies should specifically examine if these inhibitors reach targets within cells at the same rates and levels.

To confirm if inhibitors of complexes II and III can function synergistically to disrupt fungal mitochondrial respiration, TTFA/carboxin (complex II inhibitors) and AntA/Kre-Me/PCS (complex III inhibitors) were coapplied against six strains of filamentous fungal pathogens, i.e., A. fumigatus, the three $A$. terreus strains, $A$. flavus, and $P$. expansum (Table 1 ). Co-treatment of complex II and III inhibitors greatly increased their antifungal activities in comparison to each compound, alone. Most compound FICI-based interactions were either additive or synergistic, depending on types of drug combinations and/or strains tested. For example, interactions between carboxin with any of the complex III inhibitors were synergistic in all fungi tested, except with AntA in A. flavus, where it was additive. Interactions between TTFA and the complex III inhibitors were, for the most part, synergistic as well. The exceptions were additive interactions with AntA in A. terreus $\mathrm{UAB} 673$ and $A$. fumigatus and a neutral interaction in A. flavus. Collectively, results indicated that targeting complexes II and III of the MRC, simultaneously, could prove to be an effective antifungal strategy, in that their inhibitors mainly act synergistically. 
(A)

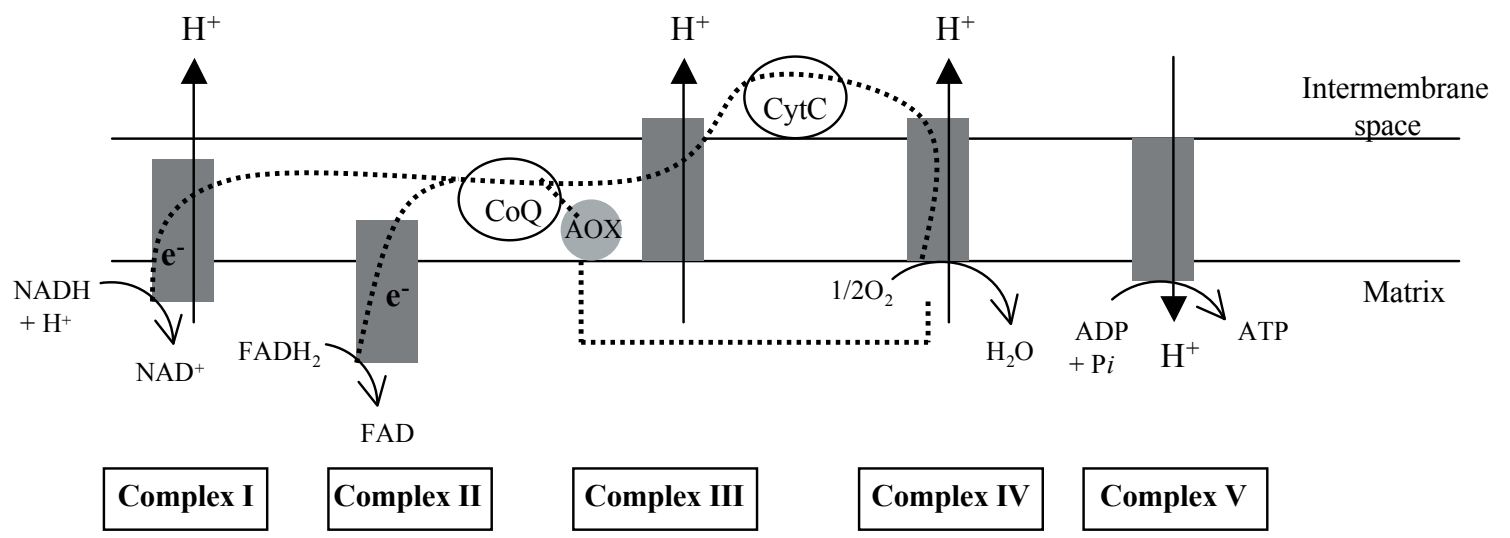

(B)

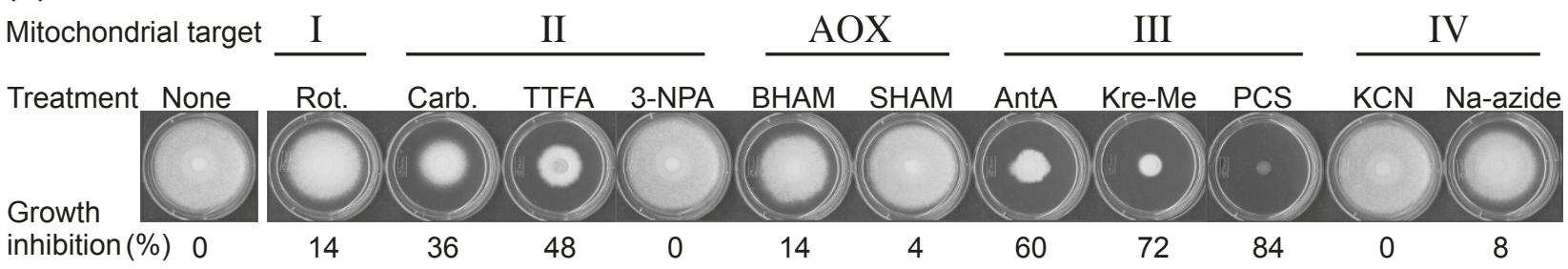

Figure 1 Targeting the mitochondrial respiratory chain. (A) Schematic representation of mitochondrial respiratory chain (Adapted from [78] and [22]. CoQ, Coenzyme Q; CytC, Cytochrome C; e', Electrons; Dashed lines, Electron flow. (B) Differential antifungal efficacy of inhibitors (0.1 mM) of mitochondrial respiration targeting complexes I to IV and alternative oxidases (AOX), tested in Aspergillus fumigatus AF293. Results indicated that targeting complex II or III by using carboxin, TTFA, antimycin A, kresoxim methyl or pyraclostrobin resulted in higher inhibition of fungal growth than targeting other complexes (\%: Growth inhibition rate, SD < 5\%). Rot, Rotenone; Carb, Carboxin; TTFA,

Thenoyltrifluoroacetone; 3-NPA, 3-Nitropropionic acid; BHAM, Benzhydroxamic acid; SHAM, Salicylhydroxamic acid; AntA, Antimycin A; Kre-Me, Kresoxim methyl; PCS, Pyraclostrobin; KCN, Potassium cyanide; Na-azide, Sodium azide. I to IV, complexes I to IV of mitochondrial respiratory chain; AOX, Alternative oxidases.

Identification of benzaldehyde analogs possessing potent antifungal activities: structure-activity relationships

Next, we examined antifungal efficacy of 21 analogs of benzaldehyde against the six different strains/species of filamentous fungi, in in vitro agar plate bioassays. Seven analogs (Figure 2A) were found that had higher antifungal activity (i.e., MIC $\leq 3.0 \mathrm{mM}$ cutoff) than other compounds. The screened compounds were categorized into four groups, based on level of antifungal activity, as follows (MICs based on average values obtained from all six filamentous fungi): Group A $(0.5<\mathrm{MIC} \leq 1.0 \mathrm{mM})-$ cinnamaldehyde, 2-hydroxy-3-methoxybenzaldehyde (ovanillin) and 2-hydroxy-5-methoxybenzaldehyde; Group B $(1.0<\mathrm{MIC} \leq 2.0 \mathrm{mM})$ - 2,5-dimethoxybenzaldehyde and 3,5-dimethoxybenzaldehyde; Group C $(2.0<\mathrm{MIC} \leq$ $3.0 \mathrm{mM}$ )- 2-methoxybenzaldehyde (o-anisaldehyde) and 2,3-dimethoxybenzaldehyde; and Group D ( MIC > 3.0 $\mathrm{mM}$ ) - the remaining 14 benzaldehyde analogs.

Structure-activity relationships were also found among the screened compounds. Firstly, the ortho-hydroxyl (2$\mathrm{OH})$ group on the aromatic ring, in general, results in higher antifungal activity compared with an ortho-methoxy (2-OMe) group (Table 2). For example, 2-hydroxy3-methoxybenzaldehyde (o-vanillin; MIC $0.67 \mathrm{mM}$ ) has $>3$-fold antifungal activity (viz., lower MIC) than 2,3dimethoxybenzaldehyde (MIC $2.5 \mathrm{mM}$ ). Likewise, 2hydroxy-5-methoxybenzaldehyde (MIC $0.58 \mathrm{mM}$ ) has again, almost three-fold greater antifungal activity than 2,5-dimethoxybenzaldehyde (MIC $1.5 \mathrm{mM}$ ). A similar comparative trend can be seen with the MICs of 2hydroxy-3-methoxybenzaldehyde or 2-hydroxy-5-methoxybenzaldehyde against that of 2-methoxybenzaldehyde (MIC $2.42 \mathrm{mM}$ ) (Table 2). [Note: Since 2-hydroxybenzaldehyde (Salicylaldehyde) is a volatile, it was not included in this study but does have antifungal and chemosensitizing activity [51]].

Antithetically, a methyl group, in general, reduced antifungal activities of benzaldehyde analogs (All methylcontaining compounds belong to the least active, Group D compounds). For example, 2-hydroxy-5-methylbenzaldehyde, generated by simple deoxygenation of the methoxy group of 2-hydroxy-5-methoxybenzaldehyde, showed 
Table 1 Antifungal interactions (FICI) between complex II and III inhibitors tested against filamentous fungi in microtiter plates ${ }^{1}$

\begin{tabular}{|c|c|c|c|c|c|c|c|c|c|}
\hline Combinations A & MIC alone & MIC combined & $\mathrm{FICl}$ & MIC alone & MIC combined & $\mathrm{FICl}$ & MIC alone & MIC combined & $\mathrm{FICl}$ \\
\hline Strains & A. terreus UAB698 & & & A. terreus UAB680 & & & A. terreus UAB673 & & \\
\hline $\begin{array}{l}\text { Kre-Me } \\
\text { Carboxin }\end{array}$ & $\begin{array}{l}>1.6^{2} \\
>128^{3}\end{array}$ & $\begin{array}{l}0.2-0.4 \\
8-16\end{array}$ & $0.19 \mathrm{~S}$ & $\begin{array}{l}>1.6 \\
>128\end{array}$ & $\begin{array}{l}0.2-0.4 \\
4-8\end{array}$ & $0.16 \mathrm{~S}$ & $\begin{array}{l}>1.6 \\
>128\end{array}$ & $\begin{array}{l}0.2-0.4 \\
8-16\end{array}$ & $0.19 \mathrm{~S}$ \\
\hline $\begin{array}{l}\text { Pyraclostrobin } \\
\text { Carboxin }\end{array}$ & $\begin{array}{l}>1.6 \\
>128\end{array}$ & $\begin{array}{l}0.0-0.05 \\
4-8\end{array}$ & $0.05 \mathrm{~S}$ & $\begin{array}{l}>1.6 \\
>128\end{array}$ & $\begin{array}{l}0.0-0.05 \\
4-8\end{array}$ & $0.05 \mathrm{~S}$ & $\begin{array}{l}>1.6 \\
>128\end{array}$ & $\begin{array}{l}0.0-0.05 \\
4-8\end{array}$ & $0.05 \mathrm{~S}$ \\
\hline $\begin{array}{l}\text { AntimycinA } \\
\text { Carboxin }\end{array}$ & $\begin{array}{l}>1.6 \\
>128\end{array}$ & $\begin{array}{l}0.4-0.8 \\
8-16\end{array}$ & $0.31 \mathrm{~s}$ & $\begin{array}{l}>1.6 \\
>128\end{array}$ & $\begin{array}{l}0.4-0.8 \\
16-32\end{array}$ & $0.38 \mathrm{~S}$ & $\begin{array}{l}>1.6 \\
>128 \\
\end{array}$ & $\begin{array}{l}0.4-0.8 \\
16-32\end{array}$ & $0.38 \mathrm{~S}$ \\
\hline Strains & A. flavus NRRL3357 & & & A. fumigatus AF293 & & & P. expansum NRRL974 & & \\
\hline $\begin{array}{l}\text { Kre-Me } \\
\text { Carboxin }\end{array}$ & $\begin{array}{l}0.4-0.8 \\
>128\end{array}$ & $\begin{array}{l}0.0-0.05 \\
0.5-1\end{array}$ & $0.07 \mathrm{~S}$ & $\begin{array}{l}>1.6 \\
>128\end{array}$ & $\begin{array}{l}0.0-0.05 \\
2-4\end{array}$ & $0.03 \mathrm{~S}$ & $\begin{array}{l}0.4-0.8 \\
32-64\end{array}$ & $\begin{array}{l}0.0-0.05 \\
0.5-1\end{array}$ & $0.08 \mathrm{~S}$ \\
\hline $\begin{array}{l}\text { Pyraclostrobin } \\
\text { Carboxin }\end{array}$ & $\begin{array}{l}0.4-0.8 \\
>128\end{array}$ & $\begin{array}{l}0.0-0.05 \\
0.125-0.25\end{array}$ & $0.06 \mathrm{~S}$ & $\begin{array}{l}0.8-1.6 \\
32-64\end{array}$ & $\begin{array}{l}0.0-0.05 \\
1-2\end{array}$ & $0.06 \mathrm{~S}$ & $\begin{array}{l}0.4-0.8 \\
2-4\end{array}$ & $\begin{array}{l}0.0-0.05 \\
0.25-0.5\end{array}$ & $0.19 \mathrm{~S}$ \\
\hline $\begin{array}{l}\text { AntimycinA } \\
\text { Carboxin }\end{array}$ & $\begin{array}{l}0.4-0.8 \\
>128\end{array}$ & $\begin{array}{l}0.2-0.4 \\
4-8\end{array}$ & $0.53 \mathrm{~A}$ & $\begin{array}{l}0.8-1.6 \\
>128\end{array}$ & $\begin{array}{l}0.2-0.4 \\
4-8\end{array}$ & $0.28 \mathrm{~S}$ & $\begin{array}{l}0.4-0.8 \\
>128\end{array}$ & $\begin{array}{l}0.05-0.1 \\
2-4\end{array}$ & $0.14 \mathrm{~S}$ \\
\hline Combinations B & MIC alone & MIC Combined & $\mathrm{FICl}$ & MIC alone & MIC combined & $\mathrm{FICl}$ & MIC alone & MIC combined & $\mathrm{FICl}$ \\
\hline Strains & A. terreus UAB698 & & & A. terreus UAB680 & & & A. terreus UAB673 & & \\
\hline $\begin{array}{l}\text { Kre-Me } \\
\text { TTFA }\end{array}$ & $\begin{array}{l}>1.6^{2} \\
>128^{3}\end{array}$ & $\begin{array}{l}0.2-0.4 \\
4-8\end{array}$ & $0.16 \mathrm{~S}$ & $\begin{array}{l}>1.6 \\
>128\end{array}$ & $\begin{array}{l}0.2-0.4 \\
16-32\end{array}$ & $0.25 \mathrm{~S}$ & $\begin{array}{l}>1.6 \\
>128\end{array}$ & $\begin{array}{l}0.2-0.4 \\
16-32\end{array}$ & $0.25 \mathrm{~S}$ \\
\hline $\begin{array}{l}\text { Pyraclostrobin } \\
\text { TTFA }\end{array}$ & $\begin{array}{l}>1.6 \\
>128\end{array}$ & $\begin{array}{l}0.1-0.2 \\
4-8\end{array}$ & $0.09 \mathrm{~S}$ & $\begin{array}{l}>1.6 \\
>128\end{array}$ & $\begin{array}{l}0.2-0.4 \\
4-8\end{array}$ & $0.16 \mathrm{~S}$ & $\begin{array}{l}>1.6 \\
>128\end{array}$ & $\begin{array}{l}0.2-0.4 \\
4-8\end{array}$ & $0.16 \mathrm{~S}$ \\
\hline $\begin{array}{l}\text { AntimycinA } \\
\text { TTFA }\end{array}$ & $\begin{array}{l}>1.6 \\
>128\end{array}$ & $\begin{array}{l}0.4-0.8 \\
32-64\end{array}$ & $0.50 \mathrm{~S}$ & $\begin{array}{l}>1.6 \\
>128\end{array}$ & $\begin{array}{l}0.4-0.8 \\
32-64\end{array}$ & $0.50 \mathrm{~S}$ & $\begin{array}{l}>1.6 \\
>128\end{array}$ & $\begin{array}{l}0.8-1.6 \\
32-64\end{array}$ & $0.75 \mathrm{~A}$ \\
\hline $\begin{array}{l}\text { Strains } \\
\text { Compounds }\end{array}$ & A. flavus NRRL3357 & & & A. fumigatus AF293 & & & P. expansum NRRL974 & & \\
\hline $\begin{array}{l}\text { Kre-Me } \\
\text { TTFA }\end{array}$ & $\begin{array}{l}>1.6 \\
>128\end{array}$ & $\begin{array}{l}0.4-0.8 \\
16-32\end{array}$ & $0.38 \mathrm{~S}$ & $\begin{array}{l}>1.6 \\
>128\end{array}$ & $\begin{array}{l}0.2-0.4 \\
8-16\end{array}$ & $0.19 \mathrm{~S}$ & $\begin{array}{l}>1.6 \\
16-32\end{array}$ & $\begin{array}{l}0.4-0.8 \\
4-8\end{array}$ & $0.50 \mathrm{~S}$ \\
\hline $\begin{array}{l}\text { Pyraclostrobin } \\
\text { TTFA }\end{array}$ & $\begin{array}{l}>1.6 \\
>128\end{array}$ & $\begin{array}{l}0.4-0.8 \\
8-16\end{array}$ & $0.31 \mathrm{~s}$ & $\begin{array}{l}>1.6 \\
>128\end{array}$ & $\begin{array}{l}0.1-0.2 \\
4-8\end{array}$ & $0.09 \mathrm{~S}$ & $\begin{array}{l}>1.6 \\
4-8\end{array}$ & $\begin{array}{l}0.05-0.1 \\
1-2\end{array}$ & $0.28 \mathrm{~S}$ \\
\hline $\begin{array}{l}\text { AntimycinA } \\
\text { TTFA }\end{array}$ & $\begin{array}{l}>1.6 \\
>128\end{array}$ & $\begin{array}{l}>1.6 \\
>128\end{array}$ & $1.00 \mathrm{~N}$ & $\begin{array}{l}>1.6 \\
>128\end{array}$ & $\begin{array}{l}0.8-1.6 \\
32-64\end{array}$ & $0.75 \mathrm{~A}$ & $\begin{array}{l}>1.6 \\
>128\end{array}$ & $\begin{array}{l}0.00-0.05 \\
8-16\end{array}$ & $0.08 \mathrm{~S}$ \\
\hline
\end{tabular}

${ }^{1}$ Compound interactions were determined as Fractional Inhibitory Concentration Indices (FICI), described by Isenberg ([47]; See also Methods). For calculation purposes, the higher concentration in each column was used. A, additive; N, neutral; S, synergistic. Complex II inhibitors ( $\mu \mathrm{g} / \mathrm{ml})$ - Carboxin, Thenoyltrifluoroacetone (TTFA); Complex III inhibitors (mM)- Kresoxim methyl (Kre-Me), Pyraclostrobin, Antimycin A. Drug

combinations for calculating FIC indices were: (Combinations A) Kre-Me + carboxin, pyraclostrobin + carboxin, and antimycin A + carboxin, and (Combinations B) Kre-Me + TFA, pyraclostrobin + TTFA, and antimycin A + TFF.

${ }^{2}$ Since antifungal test was performed up to $1.6 \mathrm{mM}$ of strobilurins or antimycin A (See Methods), $3.2 \mathrm{mM}$ (doubling of $1.6 \mathrm{mM}$ ) was used for calculation purposes.

${ }^{3}$ Since antifungal test was performed up to $128 \mu \mathrm{g} / \mathrm{ml}$ of carboxin or TTFA (See Methods), $256 \mu \mathrm{g} / \mathrm{ml}$ (doubling of $128 \mu \mathrm{g} / \mathrm{ml}$ ) was used for calculation purposes 


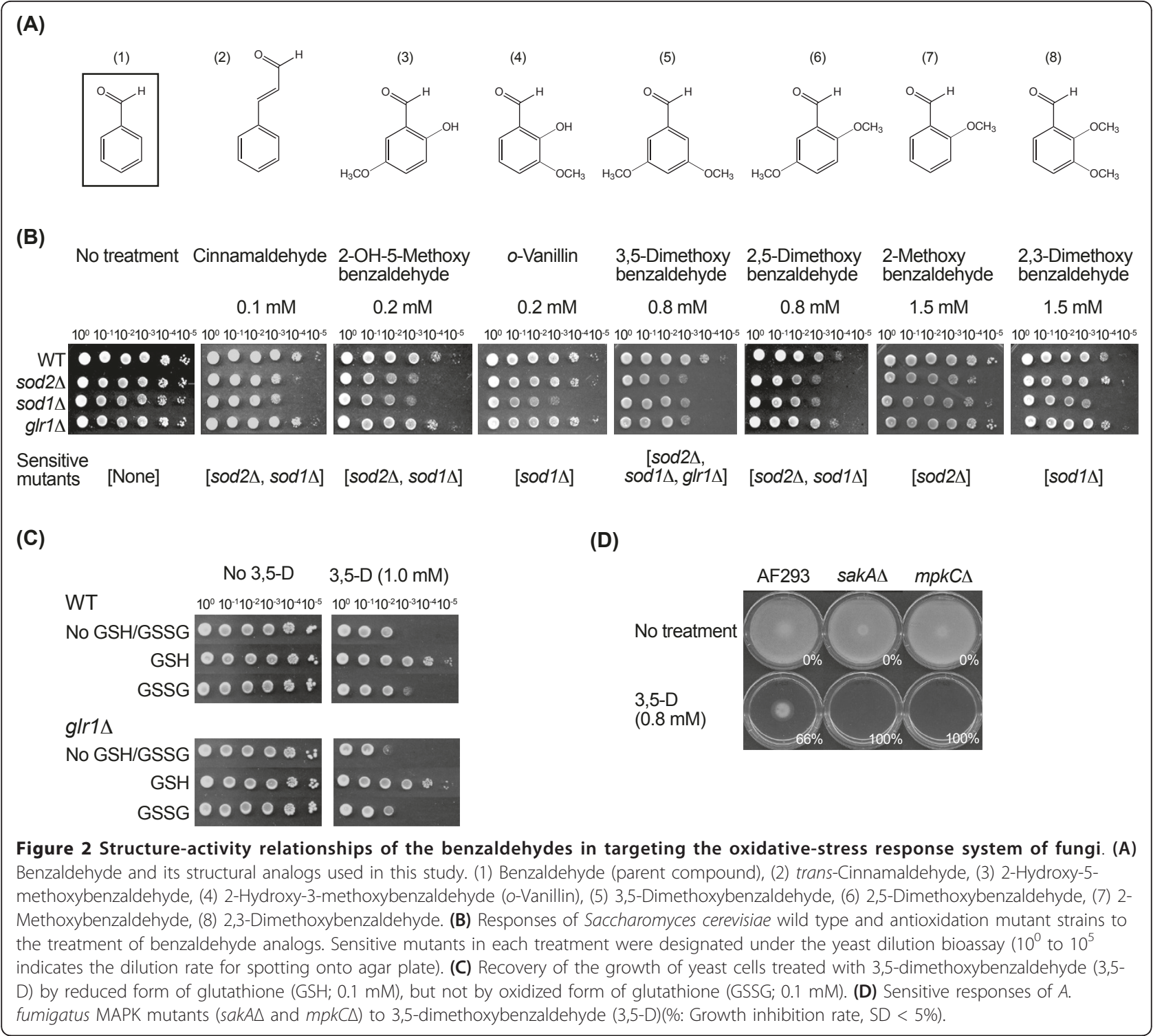

Table 2 Antifungal activities (MIC $\mathrm{mM}$ ) of benzaldehyde derivatives tested on agar against filamentous fungi

\begin{tabular}{|c|c|c|c|c|c|c|c|}
\hline Compound & $\begin{array}{l}\text { A. fumigatus } \\
\text { AF293 }\end{array}$ & $\begin{array}{l}\text { A. terreus } \\
\text { UAB673 }\end{array}$ & $\begin{array}{l}\text { A. terreus } \\
\text { UAB680 }\end{array}$ & $\begin{array}{l}\text { A. terreus } \\
\text { UAB698 }\end{array}$ & $\begin{array}{l}\text { A. flavus } \\
\text { NRRL3357 }\end{array}$ & $\begin{array}{l}\text { P. expansum } \\
\text { NRRL974 }\end{array}$ & $\begin{array}{c}\text { Mean } \\
\text { MIC }\end{array}$ \\
\hline Cinnamaldehyde & 1.0 & 0.5 & 0.5 & 0.5 & 0.5 & 0.5 & $0.58 \pm 0.20^{1}$ \\
\hline $\begin{array}{l}\text { 2-Hydroxy-5-methoxy- } \\
\text { benzaldehyde }\end{array}$ & 0.5 & 0.5 & 0.5 & 0.5 & 0.5 & 1.0 & $0.58 \pm 0.20^{1}$ \\
\hline $\begin{array}{l}\text { 2-Hydroxy-3-methoxy- } \\
\text { benzaldehyde (o-Vanillin) }\end{array}$ & 0.5 & 0.5 & 0.5 & 0.5 & 1.0 & 1.0 & $0.67 \pm 0.26^{1}$ \\
\hline 3,5-Dimethoxybenzaldehyde & 1.0 & 1.0 & 1.0 & 1.0 & 1.5 & 1.5 & $1.17 \pm 0.26^{1}$ \\
\hline 2,5-Dimethoxybenzaldehyde & 1.5 & 1.5 & 1.5 & 1.0 & 1.5 & 2.0 & $1.50 \pm 0.32^{1}$ \\
\hline $\begin{array}{l}\text { 2-Methoxybenzaldehyde } \\
\text { (o-Anisaldehyde) }\end{array}$ & 2.0 & 2.5 & 2.5 & 2.5 & 2.5 & 2.5 & $2.42 \pm 0.20^{1}$ \\
\hline 2,3-Dimethoxybenzaldehyde & 2.5 & 2.5 & 2.0 & 2.0 & 3.0 & 3.0 & $2.50 \pm 0.45^{1}$ \\
\hline $\begin{array}{l}\text { Benzaldehyde } \\
\text { (Basal structure) }\end{array}$ & $>35.0$ & $>35.0$ & $>35.0$ & $>35.0$ & $>35.0$ & $>35.0$ & $>35.0$ \\
\hline
\end{tabular}

\footnotetext{
${ }^{1} P<0.0005$ (Student's $t$ test for paired data, i.e., vs. mean MIC of benzaldehyde).
} 
a much higher MIC (> $3.0 \mathrm{mM}$ ) than the latter (MIC 0.58 $\mathrm{mM}$ ). Likewise, the MIC of 2-methylbenzaldehyde exceeds $3.0 \mathrm{mM}$, while that of 2-methoxybenzaldehyde was $2.42 \mathrm{mM}$.

Of note is that 2,3- and 2,5-dimethoxybenzaldehyde (MICs: 2.50 and $1.50 \mathrm{mM}$, respectively) have higher antifungal activity than 2,4-dimethoxybenzaldehyde (MIC: $>3.0 \mathrm{mM}$ ). This result is similar to the characteristics of quinone derivatives, where functions of enzymes/proteins are inhibited mostly by those derivatives having an ortho- or para-quinonoid structure. For example, acetaminophen, a benzoquinoid, is a known inhibitor of a macrophage migration inhibitory factor tautomerase [52]. This type of inhibitory potential may explain why a methoxy group in an ortho- or para-position also results in relatively higher antifungal activity than that in a meta-position.

\section{Effect of benzaldehydes on fungal antioxidation: $S$. cerevisiae antioxidation mutants}

Yeast dilution bioassays were performed using S. cerevisiae wild type and antioxidation mutants, $\operatorname{sod} 1 \Delta, \operatorname{sod} 2 \Delta$ and $\operatorname{glr} 1 \Delta$, against the seven most active benzaldehyde analogs. Both the $\operatorname{sod} 1 \Delta$ and $\operatorname{sod} 2 \Delta$ mutants showed reduced cell growth as represented by a two $\log _{10}$ less dilution of yeast cells before appearance of a colony when treated with cinnamaldehyde, 2-hydroxy-5-methoxybenzaldehyde, 2,5-dimethoxybenzaldehyde and 3,5dimethoxybenzaldehyde, compared to the wild type (Figure $2 \mathrm{~B})$. Additionally, the $\operatorname{sod} 1 \Delta$ mutant showed this same level of sensitivity to $o$-vanillin and 2,3-dimethoxybenzaldehyde, while $\operatorname{sod} 2 \Delta$ showed this sensitivity to 2methoxybenzaldehyde, respectively.

The glr1 $\Delta$ mutant did not show much sensitivity to any of the compounds except for 3,5-dimethoxybenzaldehyde (Figure $2 \mathrm{~B}$ ). The sensitivity to this compound is noteworthy because it suggests it disrupts cellular glutathione (gamma-L-Glutamyl-L-Cysteinylglycine; a cellular antioxidant) homeostasis. The role of Glr1p (glutathione reductase) is to replenish cellular GSH (a reduced form of glutathione) by reducing GSSG (an oxidized form of glutathione) [24]. We postulated the antifungal action of 3,5-dimethoxybenzaldehyde resulted from interference with the activity of Glr1p, which we investigated further, described below.

The $S$. cerevisiae wild type and $g l r 1 \Delta$ strains were provided with either GSH or GSSG in the presence of 3,5dimethoxybenzaldehyde $(1.0 \mathrm{mM})$. Supplementation with GSH $(0.1 \mathrm{mM})$ almost completely recovered the growth of both wild type and $g l r 1 \Delta$ strains from the toxicity of 3,5-dimethoxybenzaldehyde (Figure 2C). However, supplementation with GSSG $(0.1 \mathrm{mM})$ did not result in growth-recovery. These results, the growth recovery of the wild type and $g \operatorname{lr} 1 \Delta$ strains by GSH but not by GSSG, further indicate 3,5-dimethoxybenzaldehyde disrupts cellular glutathione homeostasis by interfering with Glr1p activity in fungi.

In summary, all seven of the "active" benzaldehydes targeted the cellular antioxidation system, such as $\mathrm{Cu}$, $\mathrm{Zn}$-SOD, Mn-SOD. In particular, one of them, 3,5dimethoxybenzaldehyde targeted Glr1p. It thus appears these systems in fungi play an important role in responding to and/or detoxifying these benzaldehydes.

\section{Effect of benzaldehydes on fungal antioxidation: $A$. fumigatus MAPK mutants}

In yeasts, such as $S$. cerevisiae and Schizosaccharomyces pombe, the regulation of SOD1, SOD2 and GLR1 genes is controlled by the MAPK signaling pathway, such as Hog1p [53]. SakA and MpkC in A. fumigatus are orthologous proteins to Hog1p of $S$. cerevisiae $[43,44]$. A. fumigatus sakA $\triangle$ is an osmotic/oxidative stress sensitive mutant, while the $m p k C \Delta$ is a mutant of the polyalcohol sugar utilization system $[43,44]$. Prior studies indicated that SakA and MpkC MAPK pathways are differentially regulated. None of the SakA-responsive cues tested, such as oxidative stressors, resulted in a common phenotype for the $m p k C \Delta$ mutant $[43,44]$. Hence, it was concluded that there were no overlapping roles between SakA and MpkC pathways.

We studied the phenotypic responses of A. fumigatus wild type and MAPK mutants, sakA $\triangle$ and $m p k C \Delta$, to the seven benzaldehydes. We wanted to determine if these compounds, like in S. cerevisiae, targeted the cellular antioxidation system in a filamentous fungus. Both mutants were more sensitive, showing no growth, when treated with $0.8 \mathrm{mM} \mathrm{3,5-dimethoxybenzaldehyde}$ (Figure 2D). The wild type strain maintained some growth, but with a $66 \%$ reduction in radial growth compared to the control. Similarly, when treated with 2,5- or 2,3-dimethoxybenzaldehyde at $0.6 \mathrm{mM}$ or 2.0 $\mathrm{mM}$, respectively, the $s a k A \Delta$ and $m p k C \Delta$ mutants showed no growth, whereas the wild type showed only a $42 \%$ or $58 \%$ reduced growth, respectively (Figure data not shown). Other benzaldehydes also inhibited the growth of the A. fumigatus MAPK mutants. Amount of compound and Vincent equation \% growth inhibition compared to the wild type (AF293: sakA $\Delta$ : $m p k C \Delta$ ) are as follows: cinnamaldehyde at $0.4 \mathrm{mM}$ (42: 59: 76), $o$-vanillin at $0.3 \mathrm{mM}(40: 88: 58), 2$ hydroxy-5-methoxybenzaldehyde at $0.4 \mathrm{mM}$ (58: 65 : 71), and 2-methoxybenzaldehyde at $0.8 \mathrm{mM}$ (14: 16: 20) (Figure data not shown).

Thus, similar to that of the antioxidation mutants of $S$. cerevisiae (Figure $2 \mathrm{~B}$ ), the sakA $\Delta$ and $m p k C \Delta$ mutants of $A$. fumigatus were more sensitive to the benzaldehydes than the wild type. These results also indicated SakA and MpkC MAPK pathways may have overlapping 
roles in response to the antifungal activity of benzaldehyde analogs.

Dimethyldithiocarbamate (DDC) is a $\mathrm{Cu}, \mathrm{Zn}-\mathrm{SOD}$ inhibitor [54]. Since an equivalent mutant to $S$. cerevisiae $\operatorname{sod} 1 \Delta$ is not currently available in A. fumigatus, we reasoned that treating $A$. fumigatus with DDC would chemically induce a phenotypic mimic of the $S$. cerevisiae $\operatorname{sod} 1 \Delta$ mutant. In a separate group of experiments, we co-applied DDC with each of the seven benzaldehydes (Groups A - C) against A. fumigatus AF293. Co-application of the benzaldehyde derivatives with DDC increased inhibition of fungal growth of the compounds alone, in all combinations. These increases were from a low of $2 \%$ (DDC+ 2,3-dimethoxybenzaldehyde) to a high of 70\% (DDC + 3,5-dimethoxybenzaldehyde), compared to the level of growth inhibition from the compounds, alone (Additional file 1 : TableS1). These increases of growth inhibition under the co-application of the compounds with an SOD inhibitor (DDC) were similar to what we observed in the yeast dilution bioassays of the compounds against the $S$. cerevisiae sod1 $1 \Delta$ mutant (Figure $2 \mathrm{~B}$ ). There is one exception. While co-application of 2 -methoxybenzaldehyde and DDC resulted in a $42 \%$ increase of growth inhibition in A. fumigatus (Additional file 1 : TableS1), the sod $1 \Delta$ mutant was discernibly insensitive to this compound (Figure 2B). This insensitivity of the $\operatorname{sod} 1 \Delta$ strain to 2-methoxybenzaldehyde may reflect the weaker antifungal activity of this compound compared to the other benzaldehydes identified.

The results with the $S$. cerevisiae mutants and with treatment of the A. fumigatus wild type with DDC indicate that both yeast and filamentous fungi respond similarly. In both types of fungi the cellular antioxidation system is a molecular target of the identified benzaldehyde analogs. The verification of the response of both a yeast and filamentous fungus to the benzaldehydes indicated the antioxidation system is a promising target to debilitate in order to increase effectiveness of fungal control agents.

\section{Chemosensitization of phenylpyrrole fungicides: using benzaldehydes to overcome fludioxonil tolerance of $A$. fumigatus MAPK mutants}

Certain fungi with mutations in genes involved in signal transduction of stress response, MAPK signaling pathway, can escape toxicity of the commercial fungicide fludioxonil [55]. Fludioxonil is a phenylpyrrole compound having a mode of action in fungi that triggers excessive stimulation of the normal, intact MAPK signaling pathway for glycerol biosynthesis [55]. The over-production of glycerol results in an "energy drain" that eventually inhibits fungal growth. We found $s a k A \Delta$ and $m p k C \Delta$, MAPK mutants of $A$. fumigatus, to be tolerant to $50 \mu \mathrm{M}$ fludioxonil, resulting in only approximately $60 \%$ growth inhibition (Figure $3 \mathrm{~A}$ ). However, co-application of sub-fungicidal levels of $o$-vanillin with fludioxonil resulted in effective chemosensitization. The $o$-vanillin plus fludioxonil pairing did not allow these mutants to develop tolerance to fludioxonil, resulting in $100 \%$ mortality (Figure $3 \mathrm{~A}$ ).

Other benzaldehydes from Groups A - C were also tested for chemosensitization capacity in combination with fludioxonil (Data not shown). These combinations also resulted in loss of tolerance of these strains to fludioxonil. It is likely that benzaldehydes directly target genes in the antioxidation system, such as $\mathrm{Cu}, \mathrm{Zn}-\mathrm{SOD}, \mathrm{Mn}-\mathrm{SOD}$,

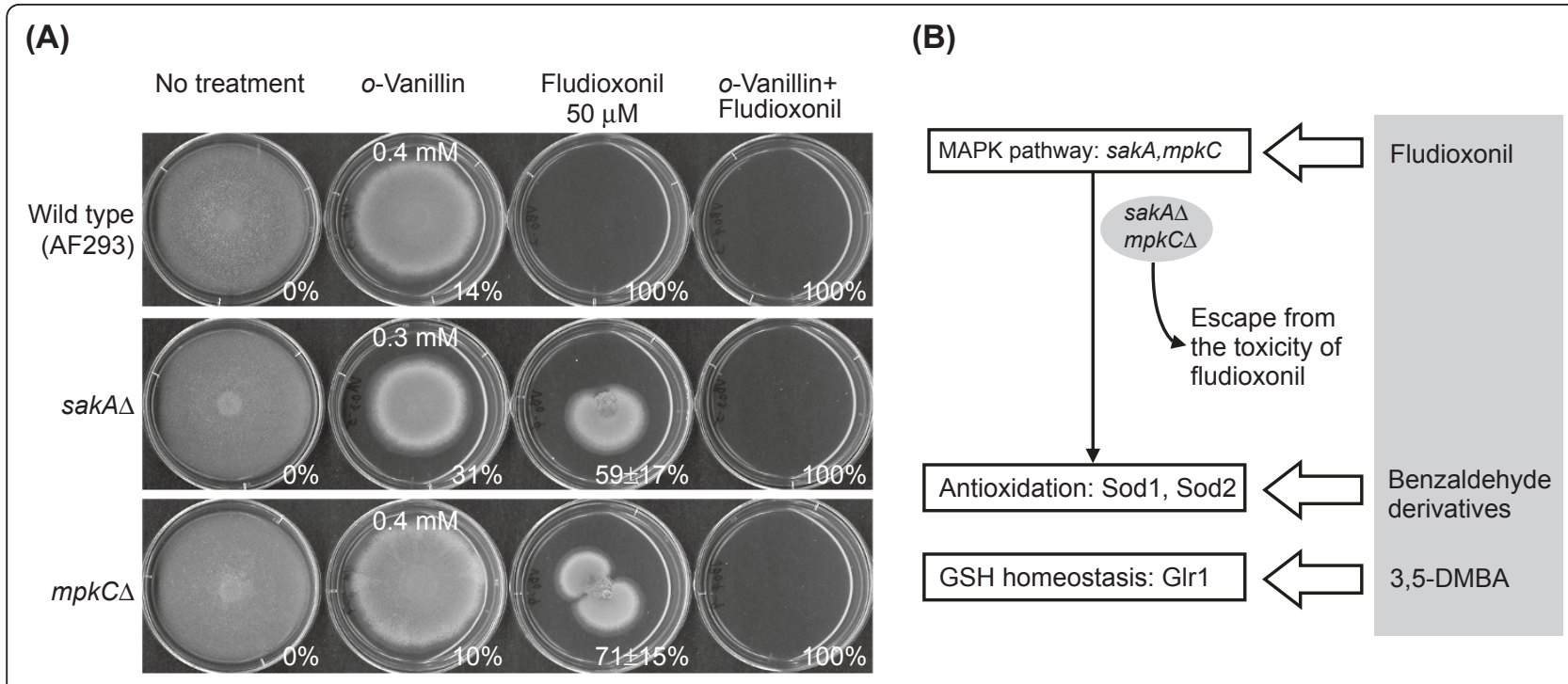

Figure 3 Overcoming fludioxonil tolerance of $A$. fumigatus MAPK mutants (sakAD and $m p k C \Delta$ ) by chemosensitization. (A) Chemosensitization by using o-vanillin (\%: Growth inhibition rate, SD < 5\% except where noted). (B) Diagram showing the strategy for efficient control of fungal pathogens by using screened benzaldehyde analogs. 3,5-DMBA, 3,5-Dimethoxybenzaldehyde. 
glutathione homeostasis, etc. These genes are downstream of their respective MAPK signaling pathways [53,56]. Hence, the chemosensitization by the benzo analogs results from bypassing the MAPK mutations and directly stressing the fungal antioxidative system (e.g., enzymes, etc.). The MAPK mutations, which had allowed tolerance to fludioxonil, now, are unable to respond to additional oxidative stress. This then results in inhibition of fungal growth by redox-active benzaldehydes (Figure 3B).

\section{Chemosensitization of inhibitors of complex II or III in MRC by using benzaldehyde analogs}

Next, we tested chemosensitizing activity of three benzaldehyde analogs (the Group A compounds showing the highest antifungal activity) in co-applications with inhibitors, carboxin or AntA, of complex II or III, respectively, the best targets in MRC (Figure 1B). Cotreatment of cinnamaldehyde, $o$-vanillin or 2-hydroxy-5methoxybenzaldehyde with AntA (a complex III inhibitor) mainly produced additive or synergistic interactions, depending on the fungal strains (FICIs, Table 3). The exceptions were $A$. flavus (cinnamaldehyde + AntA) or A. fumigatus (all treatments), which yielded neutral interactions.

Co-application of Group A compounds with carboxin (a complex II inhibitor) showed less antifungal efficacy than when co-applied with AntA (Table 3). All interactions were additive in $A$. flavus. However, in the $A$. terreus strains and $P$. expansum only additive or neutral interactions occurred. As observed with the AntA co-applications, all interactions of the Group A benzo analogs with carboxin tested in A. fumigatus were neutral. These results indicate that MRC is probably a poorer target for chemosensitization in A. fumigatus than in the other fungi.

Collectively, our results with the MRC inhibitors and coapplied benzaldehydes show that the level of antifungal interaction depends on species and strain of fungus tested. However, overall, co-application of conventional MRC inhibitors with certain natural benzaldehydes did result in some promising interactions, i.e., synergistic/additive (Table 3).

Benzaldehyde analogs as chemosensitizing agents to 2,3dihydroxybenzaldehyde or thymol, inhibitors of cell wall/ membrane integrity

In a prior study, two other natural phenolics, 2,3-dihydroxybenzaldehyde (2,3-D) and thymol, were found to interfere with fungal cell wall/membrane integrity [46]. Based on this mode of action, we reasoned that the newly identified benzaldehydes should be able to access target sites in fungi more effectively when combined with either 2,3-D or thymol. The chemosensitizing activities of the seven benzaldehydes were, thus, examined in combination with 2,3-D and thymol in all six filamentous fungal strains. The hypothesis was that these combinations should result in higher, perhaps even synergistic, antifungal activity.

Combinations of 2,3-D and the Group A - C benzaldehydes resulted in nine synergistic interactions with all others being additive, depending on the compound and strain (Additional file 2: TableS2). Hence, all of these coapplications resulted in increased antifungal activities relative to the individual application of each compound, alone, with no antagonistic or neutral interactions. Combinations of 2,3-D with $o$-vanillin, 2-hydroxy-5-methoxy-, 2,3dimethoxy-, 2,5-dimethoxy- or 2-methoxy-benzaldehyde resulted in at least one synergistic interaction. Some synergistic interactions occurred with most of the Aspergillus species/strains. All interactions with $P$. expansum or $A$. terreus UAB698 were additive.

Combinations of thymol with the screened benzaldehyde analogs all resulted in additive interactions, with the exception of cinnamaldehyde in A. flavus (synergistic) (Additional file 3: TableS3). As with 2,3-D, our results indicate that the identified benzaldehydes with thymol increased antifungal activity of each compound when combined, with no antagonistic or neutral interactions.

\section{Formulation studies: inhibition of fungal growth by using mixtures of benzo analogs}

Finally, we performed a formulation study of antifungal activity against the filamentous fungi, in which only natural benzo analogs were used. The purpose of this phase of our investigation was to determine if mixtures of our already identified benzo analogs could yield an effective level of antifungal activity, in vitro, against fungal pathogens, without a conventional antifungal drug. Formulations included the cell wall/membrane inhibitory compounds, 2,3-D and thymol, with the three Group A benzaldehydes (o-vanillin, 2-hydroxy-5-methoxybenzaldehyde and cinnamaldehyde).

Antifungal activities (i.e., MICs, MFCs, $\mathrm{FE}_{\mathrm{MIC}} \mathrm{s}$, $\mathrm{FE}_{\mathrm{MFC}} \mathrm{S}$; See Methods) of each of the benzo analogs, individually and combined as a formulation, against each of the strain/species of filamentous fungus tested are summarized in Table 4 . In all cases, when each compound was applied individually, higher concentrations (viz., higher MICs) were required for the complete inhibition of fungal growth compared to the combination of all compounds in formulations. In some cases complete inhibition of fungal growth was not achieved at the highest concentration tested $(128 \mu \mathrm{g} / \mathrm{ml})$ by the individual compounds. MICs (microtiter) for the individual compounds were as follows: $64 \mu \mathrm{g} / \mathrm{ml}$ (o-vanillin, 2-hydroxy-5-methoxybenzaldehyde, cinnamaldehyde) for all strains; > $128 \mu \mathrm{g} / \mathrm{ml}$ (thymol) for all strains; $16 \mu \mathrm{g} /$ $\mathrm{ml}$ (2,3-D) for A. fumigatus AF293/A. terreus UAB673; 
Table 3 Antifungal interactions ( $\mathrm{FICl}$ ) of benzaldehyde derivatives tested alone or in combination with antimycin A or carboxin in microtiter plates ${ }^{1}$

\begin{tabular}{|c|c|c|c|c|c|c|c|c|c|}
\hline Compounds & MIC alone & MIC combined & $\mathrm{FICl}$ & MIC: alone & MIC: combined & $\mathrm{FICl}$ & MIC: alone & MIC: combined & $\mathrm{FICl}$ \\
\hline Strains & A. terreus UAB698 & & & A. terreus UAB680 & & & A. terreus UAB673 & & \\
\hline $\begin{array}{l}\text { Cinnamaldehyde } \\
\text { Antimycin A }\end{array}$ & $\begin{array}{l}0.2-0.4 \\
>128^{2}\end{array}$ & $\begin{array}{l}0.1-0.2 \\
8-16\end{array}$ & $0.56 \mathrm{~A}$ & $\begin{array}{l}0.2-0.4 \\
>128\end{array}$ & $\begin{array}{l}0.1-0.2 \\
4-8\end{array}$ & $0.53 \mathrm{~A}$ & $\begin{array}{l}0.2-0.4 \\
>128\end{array}$ & $\begin{array}{l}0.1-0.2 \\
4-8\end{array}$ & $0.53 \mathrm{~A}$ \\
\hline $\begin{array}{l}\text { o-Vanillin } \\
\text { Antimycin A }\end{array}$ & $\begin{array}{l}0.2-0.4 \\
>128\end{array}$ & $\begin{array}{l}0.1-0.2 \\
4-8\end{array}$ & $0.53 \mathrm{~A}$ & $\begin{array}{l}0.2-0.4 \\
>128\end{array}$ & $\begin{array}{l}0.1-0.2 \\
4-8\end{array}$ & $0.53 \mathrm{~A}$ & $\begin{array}{l}0.2-0.4 \\
>128\end{array}$ & $\begin{array}{l}0.1-0.2 \\
4-8\end{array}$ & $0.53 \mathrm{~A}$ \\
\hline $\begin{array}{l}\text { 2-Hydroxy-5-methoxy } \\
\text { Antimycin A }\end{array}$ & $\begin{array}{l}0.2-0.4 \\
>128\end{array}$ & $\begin{array}{l}0.1-0.2 \\
64-128\end{array}$ & $1.00 \mathrm{~A}$ & $\begin{array}{l}0.2-0.4 \\
>128\end{array}$ & $\begin{array}{l}0.1-0.2 \\
8-16\end{array}$ & $0.56 \mathrm{~A}$ & $\begin{array}{l}0.2-0.4 \\
>128 \\
\end{array}$ & $\begin{array}{l}0.1-0.2 \\
8-16 \\
\end{array}$ & $0.56 \mathrm{~A}$ \\
\hline Strains & A. flavus NRRL3357 & & & A. fumigatus AF293 & & & P. expansum NRRL974 & & \\
\hline $\begin{array}{l}\text { Cinnamaldehyde } \\
\text { Antimycin A }\end{array}$ & $\begin{array}{l}0.2-0.4 \\
>128\end{array}$ & $\begin{array}{l}0.2-0.4 \\
>128\end{array}$ & $2.00 \mathrm{~N}$ & $\begin{array}{l}0.2-0.4 \\
>128\end{array}$ & $\begin{array}{l}0.2-0.4 \\
>128\end{array}$ & $2.00 \mathrm{~N}$ & $\begin{array}{l}0.2-0.4 \\
>128\end{array}$ & $\begin{array}{l}0.05-0.1 \\
8-16\end{array}$ & $0.31 \mathrm{~S}$ \\
\hline $\begin{array}{l}\text { o-Vanillin } \\
\text { Antimycin A }\end{array}$ & $\begin{array}{l}0.2-0.4 \\
>128\end{array}$ & $\begin{array}{l}0.1-0.2 \\
16-32\end{array}$ & $0.63 \mathrm{~A}$ & $\begin{array}{l}0.2-0.4 \\
>128\end{array}$ & $\begin{array}{l}0.2-0.4 \\
>128\end{array}$ & $2.00 \mathrm{~N}$ & $\begin{array}{l}0.2-0.4 \\
>128\end{array}$ & $\begin{array}{l}0.05-0.1 \\
4-8\end{array}$ & $0.28 \mathrm{~S}$ \\
\hline $\begin{array}{l}\text { 2-Hydroxy-5-methoxy } \\
\text { Antimycin A }\end{array}$ & $\begin{array}{l}0.2-0.4 \\
>128\end{array}$ & $\begin{array}{l}0.1-0.2 \\
64-128\end{array}$ & $1.00 \mathrm{~A}$ & $\begin{array}{l}0.2-0.4 \\
>128\end{array}$ & $\begin{array}{l}0.2-0.4 \\
>128\end{array}$ & $2.00 \mathrm{~N}$ & $\begin{array}{l}0.2-0.4 \\
>128\end{array}$ & $\begin{array}{l}0.05-0.1 \\
4-8\end{array}$ & $0.28 \mathrm{~S}$ \\
\hline Strains & A. terreus UAB698 & & & A. terreus UAB680 & & & A. terreus UAB673 & & \\
\hline $\begin{array}{l}\text { Cinnamaldehyde } \\
\text { Carboxin }\end{array}$ & $\begin{array}{l}0.2-0.4 \\
>128^{2}\end{array}$ & $\begin{array}{l}0.2-0.4 \\
>128\end{array}$ & $2.00 \mathrm{~N}$ & $\begin{array}{l}0.2-0.4 \\
>128\end{array}$ & $\begin{array}{l}0.2-0.4 \\
>128\end{array}$ & $2.00 \mathrm{~N}$ & $\begin{array}{l}0.2-0.4 \\
>128\end{array}$ & $\begin{array}{l}0.2-0.4 \\
>128\end{array}$ & $2.00 \mathrm{~N}$ \\
\hline $\begin{array}{l}\text { o-Vanillin } \\
\text { Carboxin }\end{array}$ & $\begin{array}{l}0.2-0.4 \\
>128\end{array}$ & $\begin{array}{l}0.1-0.2 \\
64-128\end{array}$ & $1.00 \mathrm{~A}$ & $\begin{array}{l}0.1-0.2 \\
>128\end{array}$ & $\begin{array}{l}0.1-0.2 \\
>128\end{array}$ & $2.00 \mathrm{~N}$ & $\begin{array}{l}0.2-0.4 \\
>128\end{array}$ & $\begin{array}{l}0.1-0.2 \\
64-128\end{array}$ & $1.00 \mathrm{~A}$ \\
\hline $\begin{array}{l}\text { 2-Hydroxy-5-methoxy } \\
\text { Carboxin }\end{array}$ & $\begin{array}{l}0.2-0.4 \\
>128\end{array}$ & $\begin{array}{l}0.1-0.2 \\
64-128\end{array}$ & $1.00 \mathrm{~A}$ & $\begin{array}{l}0.2-0.4 \\
>128\end{array}$ & $\begin{array}{l}0.1-0.2 \\
32-64\end{array}$ & $0.75 \mathrm{~A}$ & $\begin{array}{l}0.2-0.4 \\
>128\end{array}$ & $\begin{array}{l}0.1-0.2 \\
16-32\end{array}$ & $0.63 \mathrm{~A}$ \\
\hline Strains & A. flavus NRRL3357 & & & A. fumigatus AF293 & & & P. expansum NRRL974 & & \\
\hline $\begin{array}{l}\text { Cinnamaldehyde } \\
\text { Carboxin }\end{array}$ & $\begin{array}{l}0.4-0.8 \\
>128\end{array}$ & $\begin{array}{l}0.2-0.4 \\
64-128\end{array}$ & $1.00 \mathrm{~A}$ & $\begin{array}{l}0.2-0.4 \\
>128\end{array}$ & $\begin{array}{l}0.2-0.4 \\
>128\end{array}$ & $2.00 \mathrm{~N}$ & $\begin{array}{l}0.2-0.4 \\
>128\end{array}$ & $\begin{array}{l}0.1-0.2 \\
64-128\end{array}$ & $1.00 \mathrm{~A}$ \\
\hline $\begin{array}{l}\text { o-Vanillin } \\
\text { Carboxin }\end{array}$ & $\begin{array}{l}0.4-0.8 \\
>128\end{array}$ & $\begin{array}{l}0.2-0.4 \\
64-128\end{array}$ & $1.00 \mathrm{~A}$ & $\begin{array}{l}0.2-0.4 \\
>128\end{array}$ & $\begin{array}{l}0.2-0.4 \\
>128\end{array}$ & $2.00 \mathrm{~N}$ & $\begin{array}{l}0.4-0.8 \\
>128\end{array}$ & $\begin{array}{l}0.2-0.4 \\
16-32\end{array}$ & $0.63 \mathrm{~A}$ \\
\hline $\begin{array}{l}\text { 2-Hydroxy-5-methoxy } \\
\text { Carboxin }\end{array}$ & $\begin{array}{l}0.4-0.8 \\
>128\end{array}$ & $\begin{array}{l}0.2-0.4 \\
32-64\end{array}$ & $0.75 \mathrm{~A}$ & $\begin{array}{l}0.2-0.4 \\
>128\end{array}$ & $\begin{array}{l}0.2-0.4 \\
>128\end{array}$ & $2.00 \mathrm{~N}$ & $\begin{array}{l}0.2-0.4 \\
>128\end{array}$ & $\begin{array}{l}0.2-0.4 \\
>128\end{array}$ & $2.00 \mathrm{~N}$ \\
\hline
\end{tabular}

${ }^{1}$ Compound interactions were determined as Fractional Inhibitory Concentration Indices (FICI), described by Isenberg ([47]; See also Methods). For calculation purposes, the higher concentration in each column was used. A, additive; $\mathrm{N}$, neutral; S, synergistic. Benzaldehyde derivatives (mM)- cinnamaldehyde, o-vanillin, 2-hydroxy-5-methoxybenzaldehyde; Complex II inhibitor ( $\mu \mathrm{g} / \mathrm{mll}$ )- Carboxin; Complex III inhibitor ( $\mu$ g/ml)Antimycin A.

${ }^{2}$ Since antifungal test was performed up to $128 \mu \mathrm{g} / \mathrm{ml}$ of antimycin A or carboxin (See Methods), $256 \mu \mathrm{g} / \mathrm{ml}$ (doubling of $128 \mu \mathrm{g} / \mathrm{ml}$ ) was used for calculation purposes. 
Table 4 Fungicidal efficacy of benzaldehyde formulations $(\mu \mathrm{g} / \mathrm{ml})$ against individual strains of filamentous fungi examined ${ }^{1}$

\begin{tabular}{|c|c|c|c|c|c|c|c|c|}
\hline & & \multicolumn{5}{|c|}{ Compounds alone } & \multirow[b]{2}{*}{$\begin{array}{l}\text { Formulation } \\
\text { (combined) }\end{array}$} & \multirow[b]{2}{*}{$\begin{array}{l}\text { Fungicidality MFC } \text { FORMULATION } / \\
\text { MIC }_{\text {FORMULATION }}\end{array}$} \\
\hline & & Cinnamaldehyde & $\begin{array}{c}o- \\
\text { Vanillin }\end{array}$ & $\begin{array}{c}\text { 2-Hydroxy-5- } \\
\text { methoxybenzaldehyde }\end{array}$ & $2,3-D$ & Thymol & & \\
\hline $\begin{array}{l}\text { A. } \\
\text { fumigatus } \\
\text { AF293 }\end{array}$ & $\begin{array}{l}\text { MIC } \\
\left(F E_{M I C}\right) \\
\text { MFC } \\
\left(F_{\mathrm{MFC}}\right)\end{array}$ & $\begin{array}{c}32-64 \\
(8 \mathrm{H}) \\
64-128 \\
(4 \mathrm{H})\end{array}$ & $\begin{array}{l}32-64 \\
(8 \mathrm{H}) \\
>128 \\
(8 \mathrm{H})\end{array}$ & $\begin{array}{c}32-64 \\
(8 \mathrm{H}) \\
>128 \\
(8 \mathrm{H})\end{array}$ & $\begin{array}{l}\text { 8-16 } \\
(2 \mathrm{~L}) \\
>128 \\
(8 \mathrm{H})\end{array}$ & $\begin{array}{c}>128^{2} \\
(32 \mathrm{H}) \\
\mathrm{N} / \mathrm{D}^{3} \\
(8 \mathrm{H})\end{array}$ & $\begin{array}{c}4-8 \\
16-32\end{array}$ & 4 (Fungicidal) $)^{4}$ \\
\hline $\begin{array}{l}\text { A. terreus } \\
\text { UAB673 }\end{array}$ & $\begin{array}{l}\text { MIC } \\
\left(F E_{M I C}\right) \\
M F C \\
\left(F E_{M F C}\right)\end{array}$ & $\begin{array}{c}32-64 \\
(8 \mathrm{H}) \\
64-128 \\
(4 \mathrm{H})\end{array}$ & $\begin{array}{c}32-64 \\
(8 \mathrm{H}) \\
>128 \\
(8 \mathrm{H})\end{array}$ & $\begin{array}{c}32-64 \\
(8 \mathrm{H}) \\
>128 \\
(8 \mathrm{H})\end{array}$ & $\begin{array}{l}\text { 8-16 } \\
(2 \mathrm{~L}) \\
>128 \\
(8 \mathrm{H})\end{array}$ & $\begin{array}{c}>128 \\
(32 \mathrm{H}) \\
\text { N/D } \\
(8 \mathrm{H})\end{array}$ & $\begin{array}{c}4-8 \\
16-32\end{array}$ & 4 (Fungicidal) \\
\hline $\begin{array}{l}\text { A. terreus } \\
\text { UAB680 }\end{array}$ & $\begin{array}{l}\text { MIC } \\
\left(\mathrm{FE}_{\mathrm{MIC}}\right) \\
\mathrm{MFC} \\
\left(\mathrm{FE}_{\mathrm{MFC}}\right)\end{array}$ & $\begin{array}{c}32-64 \\
(4 \mathrm{H}) \\
64-128 \\
(4 \mathrm{H})\end{array}$ & $\begin{array}{l}32-64 \\
(4 \mathrm{H}) \\
>128 \\
(8 \mathrm{H})\end{array}$ & $\begin{array}{c}32-64 \\
(4 \mathrm{H}) \\
>128 \\
(8 \mathrm{H})\end{array}$ & $\begin{array}{c}16-32 \\
(2 \mathrm{~L}) \\
>128 \\
(8 \mathrm{H})\end{array}$ & $\begin{array}{c}>128 \\
(16 \mathrm{H}) \\
\mathrm{N} / \mathrm{D} \\
(8 \mathrm{H})\end{array}$ & $\begin{array}{l}8-16 \\
16-32\end{array}$ & 2 (Fungicidal) \\
\hline $\begin{array}{l}\text { A. terreus } \\
\text { UAB698 }\end{array}$ & $\begin{array}{l}\text { MIC } \\
\left(F E_{M I C}\right) \\
\text { MFC } \\
\left(F E_{M F C}\right)\end{array}$ & $\begin{array}{c}32-64 \\
(4 \mathrm{H}) \\
64-128 \\
(4 \mathrm{H})\end{array}$ & $\begin{array}{c}32-64 \\
(4 \mathrm{H}) \\
>128 \\
(8 \mathrm{H})\end{array}$ & $\begin{array}{l}32-64 \\
(4 \mathrm{H}) \\
>128 \\
(8 \mathrm{H})\end{array}$ & $\begin{array}{c}32-64 \\
(4 \mathrm{H}) \\
>128 \\
(8 \mathrm{H})\end{array}$ & $\begin{array}{c}>128 \\
(16 \mathrm{H}) \\
\mathrm{N} / \mathrm{D} \\
(8 \mathrm{H})\end{array}$ & $\begin{array}{l}8-16 \\
16-32\end{array}$ & 2 (Fungicidal) \\
\hline $\begin{array}{l}\text { A. flavus } \\
\text { NRRL3357 }\end{array}$ & $\begin{array}{l}\text { MIC } \\
\left(\mathrm{FE}_{\mathrm{MIC}}\right) \\
\mathrm{MFC} \\
\left(\mathrm{FE} \mathrm{EFC}_{\mathrm{MFC}}\right)\end{array}$ & $\begin{array}{c}32-64 \\
(4 \mathrm{H}) \\
64-128 \\
(4 \mathrm{H})\end{array}$ & $\begin{array}{c}32-64 \\
(4 \mathrm{H}) \\
>128 \\
(8 \mathrm{H})\end{array}$ & $\begin{array}{c}32-64 \\
(4 \mathrm{H}) \\
>128 \\
(8 \mathrm{H})\end{array}$ & $\begin{array}{c}64- \\
128 \\
(8 \mathrm{H}) \\
>128 \\
(8 \mathrm{H})\end{array}$ & $\begin{array}{c}>128 \\
(16 \mathrm{H}) \\
\mathrm{N} / \mathrm{D} \\
(8 \mathrm{H})\end{array}$ & $\begin{array}{l}8-16 \\
16-32\end{array}$ & 2 (Fungicidal) \\
\hline $\begin{array}{l}P . \\
\text { expansum } \\
\text { NRRL974 }\end{array}$ & $\begin{array}{l}\text { MIC } \\
\left(\mathrm{FE}_{\mathrm{MIC}}\right) \\
\mathrm{MFC} \\
\left(\mathrm{FE}_{\mathrm{MFC}}\right)\end{array}$ & $\begin{array}{c}32-64 \\
(4 \mathrm{H}) \\
32-64 \\
(2 \mathrm{~L})\end{array}$ & $\begin{array}{c}32-64 \\
(4 \mathrm{H}) \\
>128 \\
(8 \mathrm{H})\end{array}$ & $\begin{array}{c}32-64 \\
(4 \mathrm{H}) \\
>128 \\
(8 \mathrm{H})\end{array}$ & $\begin{array}{c}32-64 \\
(4 \mathrm{H}) \\
>128 \\
(8 \mathrm{H})\end{array}$ & $\begin{array}{c}>128 \\
(16 \mathrm{H}) \\
\mathrm{N} / \mathrm{D} \\
(8 \mathrm{H})\end{array}$ & $\begin{array}{l}8-16 \\
16-32\end{array}$ & 2 (Fungicidal) \\
\hline
\end{tabular}

${ }^{1}$ Efficacy of combined compounds compared to each compound alone is expressed as Formulation Efficacy ( $\mathrm{FE}_{\mathrm{MIC}}$ or $\mathrm{FE}_{\mathrm{MFC}} ;$ See Methods). $\mathrm{FE}_{\mathrm{MIC}}$ FE for MIC values; $\mathrm{FE}_{\mathrm{MFC}}$, FE for MFC values; $\mathrm{H}$ (high) if $\mathrm{FE} \geq 4, \mathrm{~L}$ (low) if $1<\mathrm{FE}<4$; See Methods for calculations. For calculation purposes, higher concentration ( $\mu \mathrm{g} / \mathrm{ml}$ ) of each concentration range was used for FE determination (e.g., 64 from $32-64 \mu \mathrm{g} / \mathrm{ml}$ ).

${ }^{2}$ Assays were conducted up to a highest concentration of $128 \mu \mathrm{g} / \mathrm{ml}$. For calculation purposes, $256 \mu \mathrm{g} / \mathrm{ml}$ (doubling of $128 \mu \mathrm{g} / \mathrm{ml}$ ) was used.

${ }^{3} \mathrm{ND}$ : Not determined since fungal growth occurred at the highest concentration $(128 \mu \mathrm{g} / \mathrm{ml})$. For calculation purposes, $256 \mu \mathrm{g} / \mathrm{ml}$ was used.

${ }^{4}$ Fungicidal or fungistatic effect was determined based on MFC FORMULATION/MIC FORMULATION ratio (Fungicidal if $\leq 4$, fungistatic if $>4$; See Methods for calculations). For calculation purposes, higher concentration $(\mu \mathrm{g} / \mathrm{ml})$ of each MIC or MFC range was used.

$32 \mu \mathrm{g} / \mathrm{ml}(2,3-\mathrm{D})$ for A. terreus UAB680; $64 \mu \mathrm{g} / \mathrm{ml}(2,3-$ D) for A. terreus UAB698/P. expansum NRRL974; 128 $\mu \mathrm{g} / \mathrm{ml}$ (2,3-D) for A. flavus NRRL3357 (Table 4). However, formulations, which included mixtures of all five compounds, completely inhibited the growth of $A$. fumigatus AF293 or A. terreus UAB673 at an MIC of 4-8 $\mu \mathrm{g} / \mathrm{ml}$ of each compound combined. Slightly higher MICs $(8-16 \mu \mathrm{g} / \mathrm{ml}$ of each compound) were needed to achieve complete growth inhibition of $A$. terreus UAB680/UAB698, A. flavus NRRL3357 or P. expansum NRRL974 (Table 4).

On the other hand, complete fungal kill (MFC) was not truly achieved with almost any of the compounds, individually (all MFCs > $128 \mu \mathrm{g} / \mathrm{ml}$ ). The only exception was for cinnamaldehyde where the MFC was $64-128 \mu \mathrm{g} /$ $\mathrm{ml}$ for all fungi except for $P$. expansum where the MFC was $32-64 \mu \mathrm{g} / \mathrm{ml}$. However, when combined in formulations, all fungi were completely killed at an MFC of 16-
$32 \mu \mathrm{g} / \mathrm{ml}$. Based on ratios of MFCs vs. MICs of the formulations (i.e., $\mathrm{MFC}_{\mathrm{FORMULATION}} / \mathrm{MIC}_{\mathrm{FORMULATION}} \leq 4$; See Table 4), all formulations were classified as "fungicidal" against all strains. The MICs of the formulations were, in some cases, $>10$ times lower than those of the compounds treated individually. Hence, combining these benzo analogs in a formulation achieved in vitro antifungal activity equivalent or within an order of magnitude (at a $\mu \mathrm{g} / \mathrm{ml}$ level) to that of currently available antifungal drugs (e.g., [57]).

Lastly, the potential contribution to formulation efficacy $\left(\mathrm{FE}_{\mathrm{MIC}}\right.$ or $\mathrm{FE}_{\mathrm{MFC}}$ reflecting individual compound antifungal activity $v s$. in a formulation; See Methods) of the individual compounds was calculated to be high $(\mathrm{H})$ (FEs $\geq 4$ ) for cinnamaldehyde, $o$-vanillin, 2-hydroxy-5methoxybenzaldehyde, 2,3-D and thymol in almost all cases (Table 4). The only exceptions were the $\mathrm{FE}_{\mathrm{MIC}} \mathrm{S}$ of 2,3-D for A. fumigatus AF293, A. terreus UAB673/ 
UAB680 or $\mathrm{FE}_{\mathrm{MFC}} \mathrm{S}$ of cinnamaldehyde for $P$. expansum NRRL974, where the values were low $(\mathrm{L})(\leq 2)$.

\section{Discussion}

Collectively, the results of this study show that certain benzaldehyde analogs can act as potent antifungal agents, or as chemosensitizing agents in concert with conventional antimycotic products, to augment their efficacy. Based on fungal gene deletion mutant bioassays, the benzaldehydes studied target the fungal cellular antioxidation system, including MAPK signaling or the antioxidation enzymes, $\mathrm{Cu}, \mathrm{Zn}$-SOD, $\mathrm{Mn}$-SOD, or glutathione reductase. These benzaldehydes also enhance, as chemosensitizing agents, the in vitro activity of conventional antifungal chemicals, such as MRC inhibitors or phenylpyrrole agents, and also natural phenolics such as 2,3-D and thymol in filamentous fungi. Co-application of benzaldehydes with other antifungal drugs, or applied in formulations of only the benzaldehydes, resulted in complete inhibition of fungal growth at much lower doses than any of the individual components applied, alone. Use of these benzaldehydes as chemosensitizing agents overcomes fungal tolerance to conventional fungicides, such as fludioxonil, and lowers dosage levels of conventional antifungal agents required for effective control.

Many antimicrobial drugs can disrupt the cellular antioxidation system of fungi. In this regard, such drugs can be considered as oxidative stress agents. Examples include MRC inhibitors and GSH depleting agents. For instance, C9-UK-2A, a structural derivative of AntA, showed potent antifungal activity against fungal pathogens, including S. cerevisiae [21,58]; pathogenic strains of $S$. cerevisiae have been isolated [58]. This drug triggers membrane injury, and induces the generation of cellular ROS against Rhodotorula mucilaginosa cells. C9-UK-2A inhibited the vegetative growth of S. cerevisiae, which also accompanies cellular and mitochondrial ROS generation [21]. This generation of ROS was due to the inhibition of electron flow at complex III in MRC. Meanwhile, treatment of fungal cells with dimethyldithiocarbamic acid or thiram [bis (dimethylthiocarbamoyl) disulfide] resulted in a rapid decrease in the level of cellular GSH, an important cellular antioxidant [59]. Consequently, the decrease in GSH will result in oxidative stress to fungi.

Other types of fungal oxidative stress agents include the phenylpyrroles, such as fludioxonil. In fungi, detection of environmental stresses, such as osmotic or oxidative stress, or cell wall disruption, is integrated into MAPK signaling pathways, which regulate downstream genes that are responsible for countering the stress $[60,61]$. Noteworthy is that mutations in fungal MAPK pathways, or upstream two-component (His-Asp phosphorelays) signaling systems, which relay environmental cues to the MAPK system, can result in tolerance to antifungal agents $[55,62,63]$. For example, fludioxonil interferes with fungal signaling systems resulting in excessive stimulation of the intact histidine kinase (HK)MAPK stress-response pathway or glycerol biosynthesis $[55,64,65]$. This stimulation is akin to the osmotic stress response, which is also linked to cellular oxidative stress ([66] and references therein). However, studies have shown that if there is a mutation in the HK-MAPK signaling system, a fungus becomes resistant to fludioxonil $[55,64]$. Hence, an intact MAPK system is required for these types of fungicides to be effective. The sakA $\Delta$ and $m p k C \triangle$ MAPK mutants of $A$. fumigatus we used in our study are vivid examples of how such mutants can be tolerant to phenylpyrroles. However, we were able to show that by applying an oxidative stress agent (such as one of the benzaldehydes), these tolerant strains became susceptible because their mutated MAPK system was incapable of launching a fully operational oxidative stress response.

Involvement of stress-inducible protein(s) in drug resistance has already been documented $[67,68]$. The heat shock protein Hsp90, an essential molecular chaperone and key regulator of cell signaling, regulates folding, transport, maturation, and degradation of cellular proteins [69-71]. In both S. cerevisiae and the opportunistic yeast pathogen Candida albicans, Hsp90 potentiates rapid evolution of drug resistance to azoles [68]. Alternatively, drug resistance was abrogated by applying inhibitors of Hsp90 [67]. Hsp90 production is induced under stress, but availability of this protein may dwindle as there is increased cellular demand as the stress continues [72].

The scenario with Hsp90 is conceptually analogous to our findings presented here. As mentioned earlier, the fungal antioxidation enzymes, such as $\mathrm{Cu}, \mathrm{Zn}-\mathrm{SOD}, \mathrm{Mn}$ SOD, glutathione reductase, etc., are necessary to contend with adverse conditions generated by oxidative stress drugs (e.g., MRC inhibitors). Accordingly, cellular demand for these enzymes can continuously increase as more and more oxidative stress is applied. Hence, redox-active benzaldehydes, such as those in our study, can be useful chemosensitizing agents when co-applied with oxidative stress drugs. In this case the fungal antioxidation system would be overwhelmed because levels of antioxidation enzymes would not be sufficient for detoxification of the concerted activities of multiple oxidative stress agents (e.g., oxidative stress drug + redoxactive chemosensitizers). Future studies may warrant a phenotypic-response screening of the entire set of deletion mutants of $S$. cerevisiae to the benzaldehydes. There is a possibility of other cellular targets to these compounds, in addition to the antioxidation system identified in our study. 
Use of antifungal agents that are MRC inhibitors can also be toxic to mammalian cells. For example, TTFA (a complex II inhibitor) can directly decrease cellular respiration, and disrupt mitochondrial membrane potential in mammalian cells [73]. Also, TTFA delays cell cycle progression, which leads to an increase of cellular ROS, glutathione oxidation and a decrease in cellular ATP levels [73]. Similarly, AntA (a complex III inhibitor) inhibits mitochondrial respiration in rat liver cells, and increases production of cellular ROS ([74] and references therein). However, potential side effects of MRC inhibitors as antifungal agents can be reduced if effective dosage levels of MRC inhibitors can be diminished. Such a reduction can be achieved by use of redox-active natural phenolics as chemosensitizers to MRC inhibitors, as shown in our study.

MRC inhibitors can also be used to enhance antifungal drugs. For example, co-application of MRC inhibitors with the antifungal drug, caspofungin (an inhibitor of cell wall integrity), greatly increased susceptibility of Candida parapsilosis to caspofungin [75]. Contrastingly, inducing the alternative respiratory pathway in MRC results in decreasing the susceptibility of C. albicans to antifungal triazole drugs [76]. Thus, use of MRC inhibitors (along with chemosensitizing agents) should be considered further for effective control of human mycoses. Another form of fungal defense, involving multidrug resistance, can also be disrupted to enhance antifungal activity. For example, in strains of $S$. cerevisiae where multidrug resistant genes PDR1, PDR3, or PDR5 are mutated, there is increased sensitivity to mucidin, an MRC inhibitor [20].

\section{Conclusions}

Cellular antioxidation systems appear to be promising molecular targets of natural phenolics for the effective control of fungi. Benzaldehyde analogs, such as those identified in this study, can be used as potent chemosensitizing agents to enhance anitmycotic activity of already available antifungal drugs. Our study focused on the effects of the tested benzaldehydes against the selected filamentous fungi. They also showed similar effects on the strains of $S$. cerevisiae, used in our study to examine mode of action. However, it is likely these benzaldehydes would have similar activity against pathogenic yeasts, such as Candida species and Cryptococcus neoformans. Certain benzaldehydes were recently reported to have chemosensitizing activity, in combination with certain antifungal drugs (amphotericin B, triazoles), against reference strains of $C$. albicans and C. neoformans [77]. Correspondingly, the benzaldehydes examined in our study, here, have potent antifungal activity against clinical strains of these yeasts (manuscript in preparation). Such chemosensitization can reduce costs, lower resistance, and alleviate health risks associated with current antifungal therapy. Further in vivo studies are necessary to determine if the in vitro activities demonstrated herein can translate to clinically effective and safe chemotherapeutic resolution of mycoses.

\section{Additional material}

\begin{abstract}
Additional file 1: Table S1. Enhanced growth inhibition of Aspergillus fumigatus AF293 by co-application of benzaldehyde derivatives and diethyldithiocarbamate (DDC) ${ }^{1}$. ${ }^{1}$ Number in each column indicates $\%$ inhibition of fungal radial growth, which was based on Vincent equation (See Methods) (SD < 5\%). Diethyldithiocarbamate (DDC): Cu,Zn-SOD (Cytosolic superoxide dismutase) inhibitor. ${ }^{2}$ The value of $\%$ increase by co-application (i.e., compound + DDC) $=$ (Vincent eq. value from co-application) - (Vincent eq. value from independent treatment, i.e., compound or DDC alone, showing higher \% growth inhibition).

Additional file 2: Table S2. Antifungal interactions (FICI) of 2,3dihydroxybenzaldehyde (2,3-D; $\mathrm{mM}$ ) and other benzaldehyde derivatives $(\mathrm{mM})$ tested alone or in combination in microtiter plates ${ }^{1} .{ }^{1}$ Compound interactions were determined as Fractional Inhibitory Concentration Indices (FICl), described by Isenberg ([47]; See Methods). For calculation purposes, the higher concentration in each column was used. A, additive; N, neutral; S, synergistic.

Additional file 3: Table S3. Antifungal interactions (FICI) of thymol $(\mathrm{mM})$ and benzaldehyde derivatives $(\mathrm{mM})$ tested alone or in combination in microtiter plates ${ }^{1} .^{1}$ Compound interactions were determined as Fractional Inhibitory Concentration Indices ( $\mathrm{FICl}$ ), described by Isenberg ([47]; See Methods). For calculation purposes, the higher concentration in each column was used. A, additive; N, neutral; S, synergistic.
\end{abstract}

\section{Abbreviations}

AntA: Antimycin A; AOX: Alternative oxidase; BHAM: Benzhydroxamic acid; CLSI: Clinical Laboratory Standards Institute; Cu,Zn-SOD: Cytosolic superoxide dismutase; 2,3-D: 2,3-Dihydroxybenzaldehyde; DDC:

Dimethyldithiocarbamate; DMSO: Dimethylsulfoxide; FFCl: Fractional Fungicidal Concentration Indices; FICl: Fractional Inhibitory Concentration Indices; GSH: Glutathione (reduced form); GSSG: Glutathione (oxidized form); KCN: Potassium cyanide; Kre-Me: Kresoxim methyl; MAPK: Mitogen-Activated Protein Kinase; MIC: Minimum Inhibitory Concentration; MFC: Minimum Fungicidal Concentration; Mn-SOD: Mitochondrial superoxide dismutase; MRC: Mitochondrial respiratory chain; Na-azide: Sodium azide; 3-NPA: 3Nitropropionic acid; PCS: Pyraclostrobin; PDA: Potato dextrose agar; ROS: Reactive oxygen species; SG medium: Synthetic glucose medium; Rot: Rotenone; SHAM: Salicylhydroxamic acid; TTFA: Thenoyltrifluoroacetone.

\section{Acknowledgements}

This research was conducted under USDA-ARS CRIS Project 5325-42000-03500D. We thank Dr. Gregory S. May at the University of Texas M.D. Anderson Cancer Center, Houston, TX for kindly providing us A. fumigatus sakA $\triangle$ and mpkC $\triangle$ strains. We also thank Dr. Arunmozhi Balajee at the Centers for Disease Control and Prevention, Atlanta, GA for kindly providing us A. terreus strains.

\section{Authors' contributions}

JHK designed and performed research including data analysis and interpretation, literature search, and wrote the manuscript. KLC and NM performed antifungal assays and prepared the figures and the final manuscript. BCC directed research and revised the manuscript. All authors have read and approved the final manuscript.

\section{Competing interests}

The authors declare that they have no competing interests.

Received: 4 March 2011 Accepted: 31 May 2011 Published: 31 May 2011 


\section{References}

1. Ostrosky-Zeichner L, Casadevall A, Galgiani JN, Odds FC, Rex JH: An insight into the antifungal pipeline: selected new molecules and beyond. Nat Rev Drug Discov 2010, 9:719-727.

2. Takimoto H, Machida K, Ueki M, Tanaka T, Taniguchi M: UK-2A, B, C and D, novel antifungal antibiotics from Streptomyces sp. 517-02. IV. Comparative studies of UK-2A with antimycin A3 on cytotoxic activity and reactive oxygen species generation in LLC-PK1 cells. J Antibiot (Tokyo) 1999, 52:480-484

3. Di Santo R: Natural products as antifungal agents against clinically relevant pathogens. Nat Prod Rep 2010, 27:1084-1098.

4. Moore CB, Sayers N, Mosquera J, Slaven J, Denning DW: Antifungal drug resistance in Aspergillus. J Infect 2000, 41:203-220.

5. Charlier C, Hart E, Lefort A, Ribaud P, Dromer F, Denning DW, Lortholary O: Fluconazole for the management of invasive candidiasis: where do we stand after 15 years? J Antimicrob Chemother 2006, 57:384-410.

6. Spanakis EK, Aperis G, Mylonakis E: New agents for the treatment of fungal infections: clinical efficacy and gaps in coverage. Clin Infect Dis 2006, 43:1060-1068.

7. Holmes AR, Lin YH, Niimi K, Lamping E, Keniya M, Niimi M, Tanabe K, Monk BC, Cannon RD: ABC transporter Cdr1p contributes more than $\mathrm{Cdr} 2 \mathrm{p}$ does to fluconazole efflux in fluconazole-resistant Candida albicans clinical isolates. Antimicrob Agents Chemother 2008, 52:3851-3862.

8. Barrett D: From natural products to clinically useful antifungals. Biochim Biophys Acta 2002, 1587:224-233.

9. Jacob MR, Walker LA: Natural products and antifungal drug discovery. Methods Mol Med 2005, 118:83-109.

10. Tawata S, Taira S, Kobamoto N, Zhu J, Ishihara M, Toyama S: Synthesis and antifungal activity of cinnamic acid esters. Biosci Biotechnol Biochem 1996, 60:909-910.

11. Florianowicz T: Penicillium expansum growth and production of patulin in the presence of benzoic acid and its derivatives. Acta Microbiol Pol 1998, 47:45-53.

12. Agarwal M, Walia S, Dhingra S, Khambay BP: Insect growth inhibition, antifeedant and antifungal activity of compounds isolated/derived from Zingiber officinale Roscoe (ginger) rhizomes. Pest Manag Sci 2001, 57:289-300.

13. Guillen $F$, Evans CS: Anisaldehyde and veratraldehyde acting as redox cycling agents for $\mathrm{H}_{2} \mathrm{O}_{2}$ production by Pleurotus eryngii. Appl Environ Microbiol 1994, 60:2811-2817.

14. Jacob C: A scent of therapy: pharmacological implications of natural products containing redox-active sulfur atoms. Natural Product Reports 2006, 23:851-863.

15. Holdom MD, Hay RJ, Hamilton AJ: The $\mathrm{Cu}, \mathrm{Zn}$ superoxide dismutases of Aspergillus flavus, Aspergillus niger, Aspergillus nidulans, and Aspergillus terreus: purification and biochemical comparison with the Aspergillus fumigatus Cu,Zn superoxide dismutase. Infect Immun 1996, 64:3326-3332

16. Hamilton AJ, Holdom MD: Antioxidant systems in the pathogenic fungi of man and their role in virulence. Med Mycol 1999, 37:375-389.

17. Washburn RG, Gallin Jl, Bennett JE: Oxidative killing of Aspergillus fumigatus proceeds by parallel myeloperoxidase-dependent and -independent pathways. Infect Immun 1987, 55:2088-2092.

18. Lee J, Kwon ES, Kim DW, Cha J, Roe JH: Regulation and the role of Cu,Zncontaining superoxide dismutase in cell cycle progression of Schizosaccharomyces pombe. Biochem Biophys Res Commun 2002, 297:854-862

19. Harris N, Costa V, MacLean M, Mollapour M, Moradas-Ferreira P, Piper PW: MnSOD overexpression extends the yeast chronological $\left(G_{0}\right)$ life span but acts independently of Sir2p histone deacetylase to shorten the replicative life span of dividing cells. Free Radic Biol Med 2003 34:1599-1606.

20. Michalkova-Papajova D, Obernauerova M, Subik J: Role of the PDR gene network in yeast susceptibility to the antifungal antibiotic mucidin. Antimicrob Agents Chemother 2000, 44:418-420.

21. Fujita K, Tani K, Usuki Y, Tanaka T, Taniguchi M: Growth inhibition dependent on reactive oxygen species generated by C9-UK-2A, a derivative of the antifungal antibiotic UK-2A, in Saccharomyces cerevisiae. J Antibiot (Tokyo) 2004, 57:511-517.
22. Ruy F, Vercesi $A E$, Kowaltowski AJ: Inhibition of specific electron transport pathways leads to oxidative stress and decreased Candida albicans proliferation. J Bioenerg Biomembr 2006, 38:129-135.

23. Longo VD, Gralla EB, Valentine JS: Superoxide dismutase activity is essential for stationary phase survival in Saccharomyces cerevisiae. Mitochondrial production of toxic oxygen species in vivo. J Biol Chem 1996, 271:12275-12280.

24. Grant CM: Role of the glutathione/glutaredoxin and thioredoxin systems in yeast growth and response to stress conditions. Mol Microbiol 2001, 39:533-541.

25. Goswami M, Mangoli SH, Jawali N: Involvement of reactive oxygen species in the action of ciprofloxacin against Escherichia coli. Antimicrob Agents Chemother 2006, 50:949-954.

26. Graybill JR, Burgess DS, Hardin TC: Key issues concerning fungistatic versus fungicidal drugs. Eur J Clin Microbiol Infect Dis 1997, 16:42-50.

27. Sokol-Anderson ML, Brajtburg J, Medoff G: Amphotericin B-induced oxidative damage and killing of Candida albicans. J Infect Dis 1986, 154:76-83.

28. Okamoto Y, Aoki S, Mataga I: Enhancement of amphotericin B activity against Candida albicans by superoxide radical. Mycopathologia 2004, 158:9-15.

29. Niimi K, Harding DR, Parshot R, King A, Lun DJ, Decottignies A, Niimi M, Lin S, Cannon RD, Goffeau A, Monk BC: Chemosensitization of fluconazole resistance in Saccharomyces cerevisiae and pathogenic fungi by a Doctapeptide derivative. Antimicrob Agents Chemother 2004, 48:1256-1271.

30. Lavigne JP, Brunel JM, Chevalier J, Pages JM: Squalamine, an original chemosensitizer to combat antibiotic-resistant gram-negative bacteria. J Antimicrob Chemother 2010, 65:799-801.

31. Denning DW: Invasive aspergillosis. Clin Infect Dis 1998, 26:781-803.

32. Leslie JF, Bandyopadhyay R, Visconti A: Mycotoxins: Detection Methods, Management, Public Health and Agricultural Trade Oxfordshire, U.K.: CAB International; 2008

33. Fliege $R$, Metzler M: The mycotoxin patulin induces intra- and intermolecular protein crosslinks in vitro involving cysteine, lysine, and histidine side chains, and alpha-amino groups. Chem Biol Interact 1999, 123:85-103.

34. Mahfoud R, Maresca M, Garmy N, Fantini J: The mycotoxin patulin alters the barrier function of the intestinal epithelium: mechanism of action of the toxin and protective effects of glutathione. Toxicol Appl Pharmacol 2002, 181:209-218.

35. Arafat W, Kern D, Dirheimer G: Inhibition of aminoacyl-tRNA synthetases by the mycotoxin patulin. Chem Biol Interact 1985, 56:333-349.

36. Arafat W, Musa MN: Patulin-induced inhibition of protein synthesis in hepatoma tissue culture. Res Commun Mol Pathol Pharmacol 1995, 87:177-186.

37. McCallum JL, Tsao R, Zhou T: Factors affecting patulin production by Penicillium expansum. J Food Prot 2002, 65:1937-1942.

38. Sabater-Vilar M, Maas RF, De Bosschere H, Ducatelle R, Fink-Gremmels J: Patulin produced by an Aspergillus clavatus isolated from feed containing malting residues associated with a lethal neurotoxicosis in cattle. Mycopathologia 2004, 158:419-426.

39. Saccharomyces Genome Database. [http://www.yeastgenome.org]

40. Parsons AB, Brost RL, Ding H, Li Z, Zhang C, Sheikh B, Brown GW, Kane PM, Hughes TR, Boone C: Integration of chemical-genetic and genetic interaction data links bioactive compounds to cellular target pathways. Nat Biotechnol 2004, 22:62-69.

41. Tonukari NJ, Scott-Craig JS, Walton JD: The Cochliobolus carbonum SNF1 gene is required for cell wall-degrading enzyme expression and virulence on maize. Plant Cell 2000, 12:237-248.

42. Kim JH, Campbell BC, Yu J, Mahoney N, Chan KL, Molyneux RJ, Bhatnagar D, Cleveland TE: Examination of fungal stress response genes using Saccharomyces cerevisiae as a model system: targeting genes affecting aflatoxin biosynthesis by Aspergillus flavus Link. Appl Microbiol Biotechnol 2005, 67:807-815.

43. Xue $T$, Nguyen CK, Romans A, May GS: A mitogen-activated protein kinase that senses nitrogen regulates conidial germination and growth in Aspergillus fumigatus. Eukaryotic Cell 2004, 3:557-560.

44. Reyes G, Romans A, Nguyen CK, May GS: Novel mitogen-activated protein kinase MpkC of Aspergillus fumigatus is required for utilization of polyalcohol sugars. Eukaryotic Cell 2006, 5:1934-1940. 
45. Vincent JM: Distortion of fungal hyphae in the presence of certain inhibitors. Nature 1947, 159:850.

46. Kim JH, Campbell B, Mahoney N, Chan K, Molyneux R, May G: Chemosensitization prevents tolerance of Aspergillus fumigatus to antimycotic drugs. Biochem Biophys Res Commun 2008, 372:266-271.

47. Isenberg HD: Clinical Microbiology Procedures Handbook. 1 edition. Washington, D. C.: American Society for Microbiology; 1992.

48. Clinical and Laboratory Standards Institute (CLSI): Reference method for broth dilution antifungal susceptibility testing of filamentous fungi: Approved standard-Second edition. CLSI document M38-A2 Wayne, PA: Clinical and Laboratory Standards Institute; 2008.

49. Meletiadis J, Antachopoulos C, Stergiopoulou T, Pournaras S, Roilides E, Walsh TJ: Differential fungicidal activities of amphotericin B and voriconazole against Aspergillus species determined by microbroth methodology. Antimicrob Agents Chemother 2007, 51:3329-3337.

50. Ingels FM, Augustijns PF: Biological, pharmaceutical, and analytical considerations with respect to the transport media used in the absorption screening system, Caco-2. J Pharm Sci 2003 92:1545-1558.

51. Kim JH, Campbell BC, Mahoney N, Chan KL, Molyneux RJ: Chemosensitization of aflatoxigenic fungi to antimycin $\mathrm{A}$ and strobilurin using salicylaldehyde, a volatile natural compound targeting cellular antioxidation system. Mycopathologia 2011, 171:291-298.

52. Senter PD, Al-Abed Y, Metz CN, Benigni F, Mitchell RA, Chesney J, Han J, Gartner CG, Nelson SD, Todaro GJ, Bucala R: Inhibition of macrophage migration inhibitory factor (MIF) tautomerase and biological activities by acetaminophen metabolites. Proc Natl Acad Sci USA 2002, 99:144-149

53. Rep M, Krantz M, Thevelein JM, Hohmann S: The transcriptional response of Saccharomyces cerevisiae to osmotic shock. Hot1p and Msn2p/Msn4p are required for the induction of subsets of high osmolarity glycerol pathway-dependent genes. J Biol Chem 2000, 275:8290-8300.

54. Maridonneau I, Braquet P, Garay RP: $\mathrm{Na}^{+}$and $\mathrm{K}^{+}$transport damage induced by oxygen free radicals in human red cell membranes. J Biol Chem 1983, 258:3107-3113.

55. Kojima K, Takano Y, Yoshimi A, Tanaka C, Kikuchi T, Okuno T: Fungicide activity through activation of a fungal signalling pathway. Mol Microbiol 2004, 53:1785-1796.

56. Rep M, Proft M, Remize F, Tamas M, Serrano R, Thevelein JM, Hohmann S: The Saccharomyces cerevisiae Sko1p transcription factor mediates HOG pathway-dependent osmotic regulation of a set of genes encoding enzymes implicated in protection from oxidative damage. Mol Microbiol 2001, 40:1067-1083.

57. Yamazaki T, Inagaki Y, Fujii T, Ohwada J, Tsukazaki M, Umeda I, Kobayashi K, Shimma N, Page MG, Arisawa M: In vitro activity of isavuconazole against 140 reference fungal strains and 165 clinically isolated yeasts from Japan. Int J Antimicrob Agents 2010, 36:324-331.

58. McCusker JH, Clemons KV, Stevens DA, Davis RW: Genetic characterization of pathogenic Saccharomyces cerevisiae isolates. Genetics 1994, 136:1261-1269.

59. Elskens MT, Penninckx MJ: Thiram and dimethyldithiocarbamic acid interconversion in Saccharomyces cerevisiae: a possible metabolic pathway under the control of the glutathione redox cycle. Appl Environ Microbiol 1997, 63:2857-2862.

60. Schwartz MA, Madhani HD: Principles of MAP kinase signaling specificity in Saccharomyces cerevisiae. Annu Rev Genet 2004, 38:725-748.

61. Levin DE: Cell wall integrity signaling in Saccharomyces cerevisiae. Microbiol Mol Biol Rev 2005, 69:262-291.

62. Motoyama T, Kadokura K, Ohira T, Ichiishi A, Fujimura M, Yamaguchi I, Kudo T: A two-component histidine kinase of the rice blast fungus is involved in osmotic stress response and fungicide action. Fungal Genet Biol 2005, 42:200-212.

63. Hagiwara D, Matsubayashi Y, Marui J, Furukawa K, Yamashino T, Kanamaru K, Kato M, Abe K, Kobayashi T, Mizuno T: Characterization of the NikA histidine kinase implicated in the phosphorelay signal transduction of Aspergillus nidulans, with special reference to fungicide responses. Biosci Biotechnol Biochem 2007, 71:844-847.

64. Ochiai N, Fujimura M, Motoyama T, Ichiishi A, Usami R, Horikoshi K, Yamaguchi I: Characterization of mutations in the two-component histidine kinase gene that confer fludioxonil resistance and osmotic sensitivity in the os-1 mutants of Neurospora crassa. Pest Manag Sci 2001, 57:437-442.

65. Kanetis L, Forster H, Jones CA, Borkovich KA, Adaskaveg JE: Characterization of genetic and biochemical mechanisms of fludioxonil and pyrimethanil resistance in field isolates of Penicillium digitatum. Phytopathology 2008, 98:205-214.

66. Boisnard S, Ruprich-Robert G, Florent M, Da Silva B, Chapeland-Leclerc F, Papon N: Role of Sho1p adaptor in the pseudohyphal development, drugs sensitivity, osmotolerance and oxidant stress adaptation in the opportunistic yeast Candida lusitaniae. Yeast 2008, 25:849-859.

67. Cowen LE, Lindquist S: Hsp90 potentiates the rapid evolution of new traits: drug resistance in diverse fungi. Science 2005, 309:2185-2189.

68. Cowen LE, Carpenter AE, Matangkasombut O, Fink GR, Lindquist S: Genetic architecture of Hsp90-dependent drug resistance. Eukaryot Cell 2006, 5:2184-2188

69. Young JC, Moarefi I, Hartl FU: Hsp90: a specialized but essential proteinfolding tool. J Cell Biol 2001, 154:267-273.

70. Picard D: Heat-shock protein 90, a chaperone for folding and regulation. Cell Mol Life Sci 2002, 59:1640-1648.

71. Pratt WB, Toft DO: Regulation of signaling protein function and trafficking by the hsp90/hsp70-based chaperone machinery. Exp Biol Med (Maywood) 2003, 228:111-133.

72. Sangster TA, Lindquist S, Queitsch C: Under cover: causes, effects and implications of Hsp90-mediated genetic capacitance. Bioessays 2004, 26:348-362.

73. Byun HO, Kim HY, Lim JJ, Seo YH, Yoon G: Mitochondrial dysfunction by complex II inhibition delays overall cell cycle progression via reactive oxygen species production. J Cell Biochem 2008, 104:1747-1759.

74. Fostel JM, Lartey PA: Emerging novel antifungal agents. Drug Discov Today 2000, 5:25-32.

75. Chamilos G, Lewis RE, Kontoyiannis DP: Inhibition of Candida parapsilosis mitochondrial respiratory pathways enhances susceptibility to caspofungin. Antimicrob Agents Chemother 2006, 50:744-747.

76. Yan L, Li M, Cao Y, Gao P, Cao Y, Wang Y, Jiang Y: The alternative oxidase of Candida albicans causes reduced fluconazole susceptibility. J Antimicrob Chemother 2009, 64:764-773.

77. Faria NCG, Kim JH, Gonçalves LAP, Martins MdeL, Chan KL, Campbell BC: Enhanced activity of antifungal drugs using natural phenolics against yeast strains of Candida and Cryptococcus. Lett Appl Microbiol 2011, 52:506-513.

78. McIntosh L: Molecular biology of the alternative oxidase. Plant Physiol 1994, 105:781-786.

doi:10.1186/1476-0711-10-23

Cite this article as: Kim et al: Antifungal activity of redox-active benzaldehydes that target cellular antioxidation. Annals of Clinical Microbiology and Antimicrobials 2011 10:23.

\section{Submit your next manuscript to BioMed Central and take full advantage of:}

- Convenient online submission

- Thorough peer review

- No space constraints or color figure charges

- Immediate publication on acceptance

- Inclusion in PubMed, CAS, Scopus and Google Scholar

- Research which is freely available for redistribution

Submit your manuscript at www.biomedcentral.com/submit
C Biomed Central 